Review

\title{
Natural Products as Source of Potential Dengue Antivirals
}

Róbson Ricardo Teixeira ${ }^{1, *}$, Wagner Luiz Pereira ${ }^{1}$, Ana Flávia Costa da Silveira Oliveira ${ }^{2,4}$, Adalberto Manoel da Silva ${ }^{1}$, André Silva de Oliveira ${ }^{2,4}$, Milene Lopes da Silva ${ }^{1}$, Cynthia Cânedo da Silva ${ }^{3}$ and Sérgio Oliveira de Paula ${ }^{4, *}$

1 Departamento de Química, Universidade Federal de Viçosa, 36570-900 Viçosa, MG, Brazil

2 Instituto Federal de Educação, Ciência e Tecnologia do Norte de Minas, 39900-000 Almenara, MG, Brazil

3 Departamento de Microbiologia, Universidade Federal de Viçosa, 36570-900 Viçosa, MG, Brazil

4 Departamento de Biologia Geral, Universidade Federal de Viçosa, 36570-900 Viçosa, MG, Brazil

* Authors to whom correspondence should be addressed: E-Mails: robsonr.teixeira@ufv.br (R.R.T.); depaula@ufv.br (S.O.P.); Tel.: +55-31-3899-3209 (R.R.T.); +55-31-3899-2589 (S.O.P.);

Fax: +55-31-3899-2370 (R.R.T.); +55-31-3899-2549 (S.O.P.).

Received: 14 March 2014; in revised form: 4 June 2014 / Accepted: 5 June 2014 /

Published: 17 June 2014

Abstract: Dengue is a neglected disease responsible for 22,000 deaths each year in areas where it is endemic. To date, there is no clinically approved dengue vaccine or antiviral for human beings, even though there have been great efforts to accomplish these goals. Several approaches have been used in the search for dengue antivirals such as screening of compounds against dengue virus enzymes and structure-based computational discovery. During the last decades, researchers have turned their attention to nature, trying to identify compounds that can be used as dengue antivirals. Nature represents a vast reservoir of substances that can be explored with the aim of discovering new leads that can be either used directly as pharmaceuticals or can serve as lead structures that can be optimized towards the development of new antiviral agents against dengue. In this review we describe an assortment of natural products that have been reported as possessing dengue antiviral activity. The natural products are organized into classes of substances. When appropriate, structure-activity relationships are outlined. The biological assays used to assess antiviral activity are briefly described.

Keywords: dengue virus; dengue fever; antiviral natural products 


\section{Introduction}

Dengue fever (DF) and dengue hemorrhagic fever (DHF) are acute febrile diseases transmitted by mosquitoes. Nowadays, they are the most rapidly spreading mosquito-borne diseases in the world. About 2.5 billion people, two-fifths of the world's population, are now at risk of infection and 50 million cases of DF are reported worldwide every year [1]. In recent decades, these diseases have spread to over more than 100 countries [2]. The World Health Organization (WHO) estimates that the annual global incidence of dengue is close to 390 million, a number nearly three times higher than the number of cases estimated by the same organization for 2009 [3].

Increased urbanization along with substandard housing, unreliable water supply, and poor sanitation provide a suitable environment for vector proliferation in close proximity to human hosts. Dengue proliferation became even more problematic in the Americas due to the collapse of vector eradication programs in the 1970s [4].

The dengue virus particle is about $50 \mathrm{~nm}$ in diameter. The 10,723-nucleotide RNA genome encodes an uninterrupted open reading frame (ORF), directing the synthesis of a polyprotein precursor in the order $\mathrm{NH}_{2}$-C-prM-E-NS1-NS2A-NS2B-NS3-NS4A-NS4B-NS5-COOH, where $\mathrm{C}$ is the capsid protein, $\mathrm{M}$ is the membrane-associated protein, $\mathrm{E}$ is the envelope protein, and NS1 through NS5 are nonstructural proteins [5].

The disease has four viral serotypes (DENV 1-4), and its spectrum ranges from asymptomatic infection to dengue fever (DF), dengue hemorrhagic fever (DHF), and dengue shock syndrome (DSS), and may lead to patient death [6]. All four serotypes of dengue virus are transmitted to humans by the Aedes aegypti and Aedes albopictus mosquitoes [7].

During a dengue outbreak that struck Malaysia's Sarawak state, on Borneo, blood and serum samples from a severe case labeled "dengue 4" were collected, and later, the sequence of the genome showed that the virus occupies a new branch on the dengue family tree, suggesting the serotype DENV-5 [3]. Provided that this new serotype is transmissible as DENV 1-4, it might follow a similar pattern of geographical spread as described by Messina and co-workers. By using several maps, the authors demonstrated the expansion of the serotypes throughout the world, the growth of hyperendemicity (coexistence of multiple serotypes), and the establishment of dengue as an important infectious disease of global public health importance [8].

To date, there is no clinically approved dengue vaccine or antiviral for humans, even though there have been great efforts towards this end. The treatment of the disease is limited to supportive care $[9,10]$ with analgesics, fluid replacement and bed rest [11]. Aspirin, non-steroidal anti-inflammatory drugs (NSAIDs), and corticosteroids should be avoided. Special attention should be given to severe cases of dengue in terms of fluid administration and treatment of hemorrhage. A placebo-controlled, double-blind investigation was conducted with sixty-three children having severe dengue shock syndrome in two hospitals in Thailand. The children were completely randomized into two groups. One of the groups was treated with a single dose of steroidal drug methylprednisolone and a placebo was administered to the other group. The study revealed that there was no significant difference in mortality between the groups [12].

The cost of dengue to society is considerable, from lost wages and diminished productivity to costs related to care-giving and direct medical expenses. The cost of dengue in the Western Hemisphere 
alone is estimated to be US\$2.1 billion per year [13]. In view of these problems, an efficient dengue vaccine or antiviral is highly desirable.

Different approaches have been used in the search for dengue antivirals, such as screening of compounds against dengue enzymes [14] and structure-based computational discovery [15]. During the last decades, researchers have turned their attention to nature, trying to identify compounds that can be used as dengue antivirals. In fact, nature is a fantastic reservoir of substances that can be used directly as pharmaceuticals or can serve as lead structures that can be optimized towards the development of new therapeutic agents [16-23].

Several plants around the world present potential dengue antiviral activity. Recently, Kadir and co-workers reviewed sixty nine studies from 1997 to 2012 related to plants presenting potential antidengue activity [24]. It should be mentioned that according to a WHO factsheet, $80 \%$ of the population in some Asian and African countries depends on traditional medicine as their primary health care due to economic and geographical constraints [25-27]. In view of their few (or lack of) adverse effetcts, the world-wide use of medicinal plants or herbal-based medicine is steadily growing.

Even though a number of plants are known for their antidengue activity, few investigations have been published related to isolation (identification) of compounds from plants and subsequent evaluation of their dengue antiviral activities. We describe in this review several investigations which resulted in the isolation (or identification) of compounds endowed with antiviral dengue activity, most of them isolated from plants. The review also covers metabolites isolated from other natural sources.

\section{Polysaccharides}

Fucoidans are a group of polysaccharides which contain considerable percentages of L-fucose and sulfate ester groups. These compounds are mainly derived from brown seaweed, and several bioactivities have been described for them, including antiviral ones [28-30]. Fucoidan (1, Figure 1), is a polysaccharide isolated from the marine alga brown seaweed Cladosiphon okamuranus. Its structure is composed of repeating units of sulphated fucose and glucuronic acid residues. The investigation conducted with Cladosiphon fucoidan (1) demonstrated that this polysaccharide inhibits dengue virus type 2 (DENV-2) infection [31]. The biological assays to evaluate antiviral activity were conducted in vitro by focus-forming assay using BHK-21 cells. Compound $\mathbf{1}$ inhibited virus infection in a concentration-dependent matter. When the virus was treated with $10 \mu \mathrm{g} / \mathrm{mL}$ of fucoidan (1), infectivity by dengue virus serotype 2 was reduced by $80 \%$ compared with that in untreated cells and the determined $\mathrm{IC}_{50}$ corresponded to $4.7 \mu \mathrm{g} / \mathrm{mL}$. Dengue virus serotypes 3 and 4 were moderately susceptible to 1. For serotype 1, fucoidan (1) did not present an effect on the infection. Fucoidan derivatives (2-4) (Figure 1) were also examined for their effects on infection of BHK-21 cells by dengue virus serotype 2. Polysaccharide $\mathbf{2}$ is a derivative obtained by removal of the sulfated groups in fucoidan (1); derivative $\mathbf{3}$ was prepared by reduction of fucoidan (1). Fucan (4) is a fucose polymer. 
Figure 1. Fucoidan (1) and derivatives 2-4.

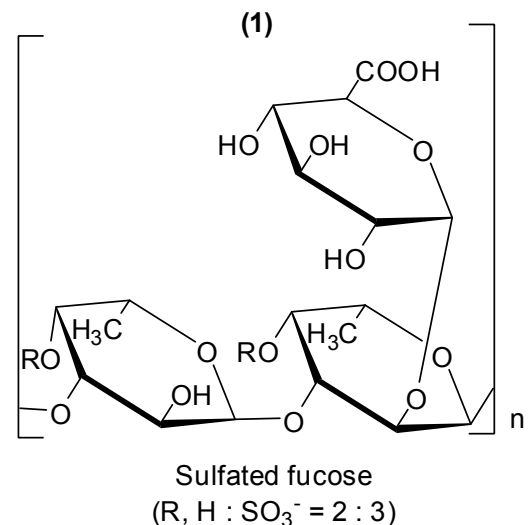

(3)

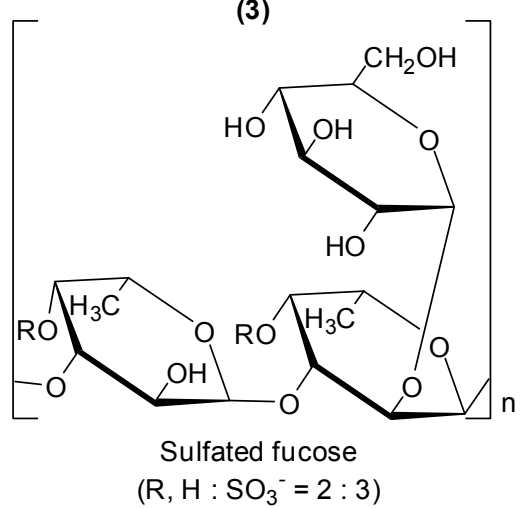

(2)

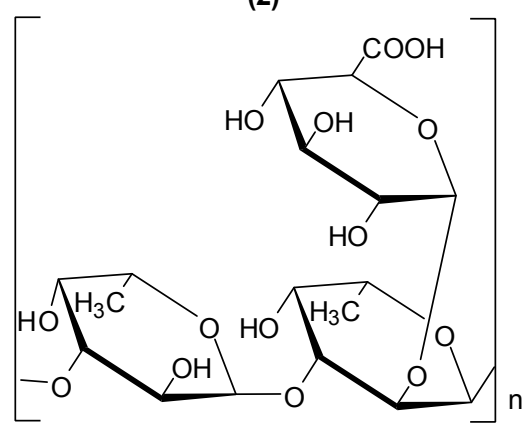

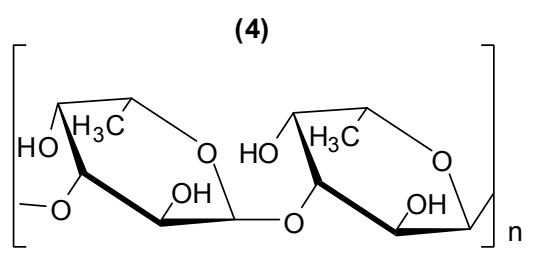

The desulfation of fucoidan (1) led to derivatives $\mathbf{2}$ and $\mathbf{4}$ which showed remarkable suppression of inhibitory activity. This finding is in agreement with previous investigations which demonstrated that sulfation is required for the antiviral activity of glycosaminoglycans [32]. Even though compound $\mathbf{3}$ is a sulfated derivative, the reduction of carboxylic acid functionality in fucoidan (1) to the corresponding alcohol also resulted in a decrease of the capability of $\mathbf{3}$ in preventing serotype 2 virus infection. Therefore, it was concluded that the glucuronic acid residue as well as the sulphate groups are fundamental for the inhibitory activity of fucoidan (1) against DENV-2 [31]. It was also reported that glucuronic acid and sulfated fucose residues of the Cladosiphon fucoidan appear to critically affect the interaction of DENV-2 with cellular receptors, but the precise molecular mechanism of the inhibitory effects of this compound has not been elucidated.

Several polysaccharides known as galactans have been isolated from red seaweeds [33-36]. The structures of these compounds correspond to a linear chain of $\beta$-D-galactopyranose residues linked by positions 1 and 3 (Figure 2, unit A) and residues of $\alpha$-galactopyranose linked by positions 1 and 4 (Figure 2, unit B) resulting in an arrangement in which units A and B are alternating. Natural chemical modifications in these structures include the presence of sulfate esters groups, pyruvate acetal and/or methyl ethers. In addition, unit B can exist in the 3,6-anhydro- $\alpha$-galactopyranose form. 
Figure 2. Repeating basic structure of galactans.

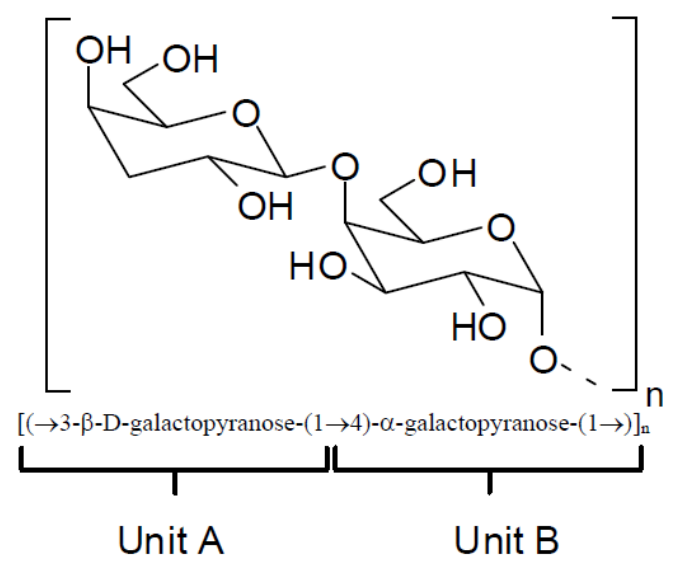

Depending on the stereochemistry of unit B (Figure 2), the galactans can be classified as follows: (i) carrageenans - these correspond to sulfated polysaccharides with 4-linked $\alpha$-galactose residues of the D-series or their 3,6-anhydro derivatives (Figure 3). Carrageenans are typically classified according to their structural features, including their sulfation patterns and the presence or absence of 3,6-anhydro$\alpha$-galactopyranose on D-units. There are at least 15 different carrageenan structures, the most relevant being iota, kappa [Figure 3, (I)], lambda, mu, and $n u$ [Figure 3, (II)] [37]. It is important to mention that natural carrageenans typically occur as mixtures of different hybrids. Moreover, methyl or pyruvic acid acetal moieties and the presence of small amounts of other sugars can add to the structures of these polysaccharides [37].

Figure 3. Repeating structures of carrageenans.

(l)

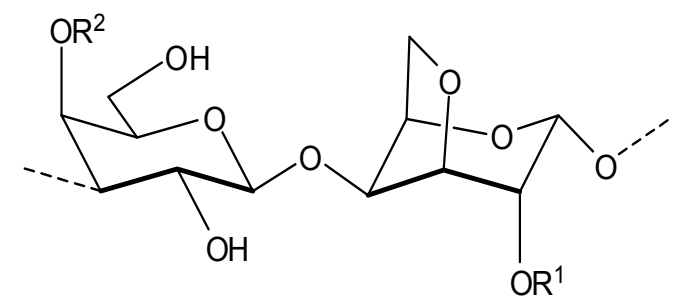

lota: $\quad \mathrm{R}^{1}=\mathrm{R}^{2}=\mathrm{SO}_{3}^{-}$

Kappa: $\mathrm{R}^{1}=\mathrm{H}, \mathrm{R}^{2}=\mathrm{SO}_{3}^{-}$
(II)

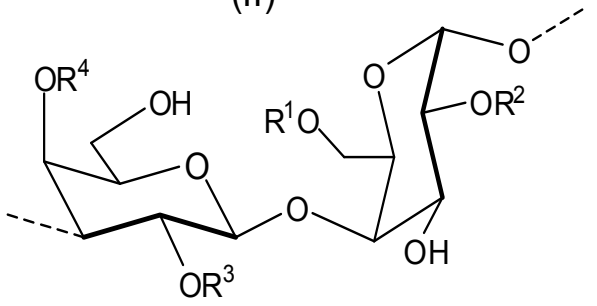

Lambda: $\mathrm{R}^{1}=\mathrm{SO}_{3}^{-}, \mathrm{R}^{2}=\mathrm{SO}_{3}^{-}, \mathrm{R}^{3}=\mathrm{SO}_{3}^{-}, \mathrm{R}^{4}=\mathrm{H}$

$\mathrm{Mu}: \quad \mathrm{R}^{1}=\mathrm{SO}_{3}^{-}, \mathrm{R}^{2}=\mathrm{H}, \mathrm{R}^{3}=\mathrm{H}, \mathrm{R}^{4}=\mathrm{SO}_{3}^{-}$

$\mathrm{Nu}: \quad \mathrm{R}^{1}=\mathrm{SO}_{3}^{-}, \mathrm{R}^{2}=\mathrm{SO}_{3}^{-}, \mathrm{R}^{3}=\mathrm{H}, \mathrm{R}^{4}=\mathrm{SO}_{3}^{-}$

(ii) agarans - this group of galactans differs from carrageenans in terms of the stereochemistry of unit B. For the agarans, the 4-linked $\alpha$-galactose residues unit b correspond to the L-series.

(iii) DL-hybrids - these galactans are characterized by the presence of 4-linked $\alpha$-galactose residues of the D and L series in the same molecule. Figure 4 depicts the basic repeating structure of DL-hybrid galactans. 
Figure 4. Basic repeating unit of DL-hybrid galactans.

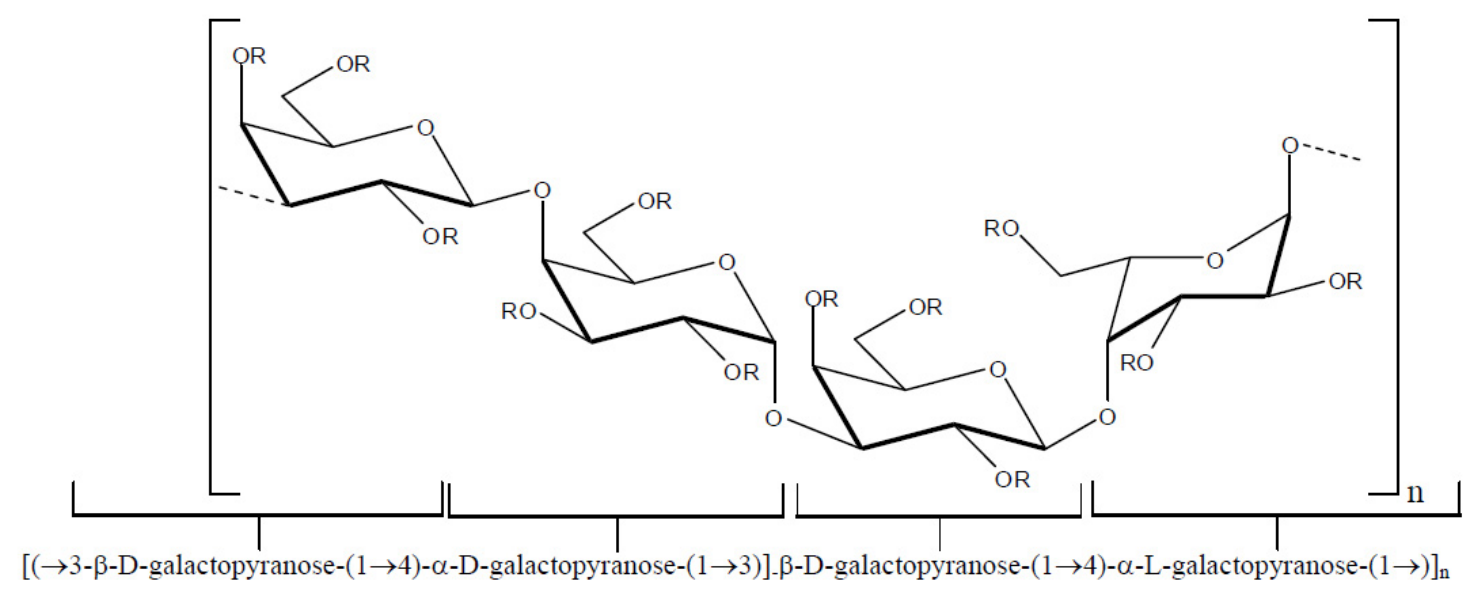

Commercially available iota, kappa and lambda carrageenans (Figure 3) were evaluated against DENV 1-4 serotypes [38]. The assays were conducted in vitro, using Vero and HepG2 cells and the activity of carrageenans was initially tested by plaque reduction assays, necessarily performed at a low multiplicity of infection (m.o.i.), but then confirmed by inhibition of virus yield and antigen expression assays, accomplished at high m.o.i. The polysaccharides were more effective on DENV-2 and DENV-3 serotypes. It was also determined that the carrageenans lambda and iota are potent inhibitors of DENV-2 and DENV-3 multiplication in Vero and HepG2 cells with $\mathrm{EC}_{50}$ (effective concentration 50\%) ranging from 0.14 to $4.1 \mu \mathrm{g} / \mathrm{mL}$ (Table 1). The results showed that the lack of dependence of the antiviral potency of carrageenans on the infecting virus inoculum was even more evident when the assays were performed simultaneously at a wide range of multiplicities. This important property represents a clear advantage for those compounds able to block infection even in the presence of high initial virus doses.

Table 1. $\mathrm{EC}_{50}$ values for inhibition of DEN-2 and DENV-3 multiplication in Vero and HepG2 cells.

\begin{tabular}{ccc}
\hline \multirow{2}{*}{ Polysaccharide } & \multicolumn{2}{c}{$\mathbf{E C}_{\mathbf{5 0}}(\boldsymbol{\mu g} / \mathbf{m L})$} \\
\cline { 2 - 3 } & Vero Cells & HepG2 cells \\
\hline DENV-2 & & \\
iota-carrageenan & $0.4 \pm 0.1$ & $0.14 \pm 0.01$ \\
lambda-carrageenan & $0.22 \pm 0.02$ & $0.17 \pm 0.01$ \\
DENV-3 & & \\
iota -carrageenan & $1.1 \pm 0.1$ & $0.63 \pm 0.01$ \\
lambda -carrageenan & $0.6 \pm 0.1$ & $0.63 \pm 0.01$ \\
\hline
\end{tabular}

This study was able to demonstrate that a heparin sulfate (HS) imitative compound lambda had the ability to interfere with DENV-2 replication when added after virus adsorption, and even under these conditions, the antiviral potential of lambda-carrageenan was higher than its ability to affect virus adsorption. The mechanism of the inhibitory multiplication effect of the iota carrageenan was not described.

Talarico and co-workers investigated the dengue antiviral activity of two sulfated polysaccharides obtained from the read seaweeds Gymnogongrus griffithsiae and Cryptonemia crenulata [39]. The G3d 
compound obtained from G. griffithsiae is a carrageenan composed of kappa/iota/nu repeating units (see Figure 3). The DL-galactan hybrid $C 2 S-3$ obtained from $C$. crenulata is made of the units disaccharide units (a), (b), and (c) shown in Figure 5.

Figure 5. Disaccharides units present in the structure of $C 2 S-3$.
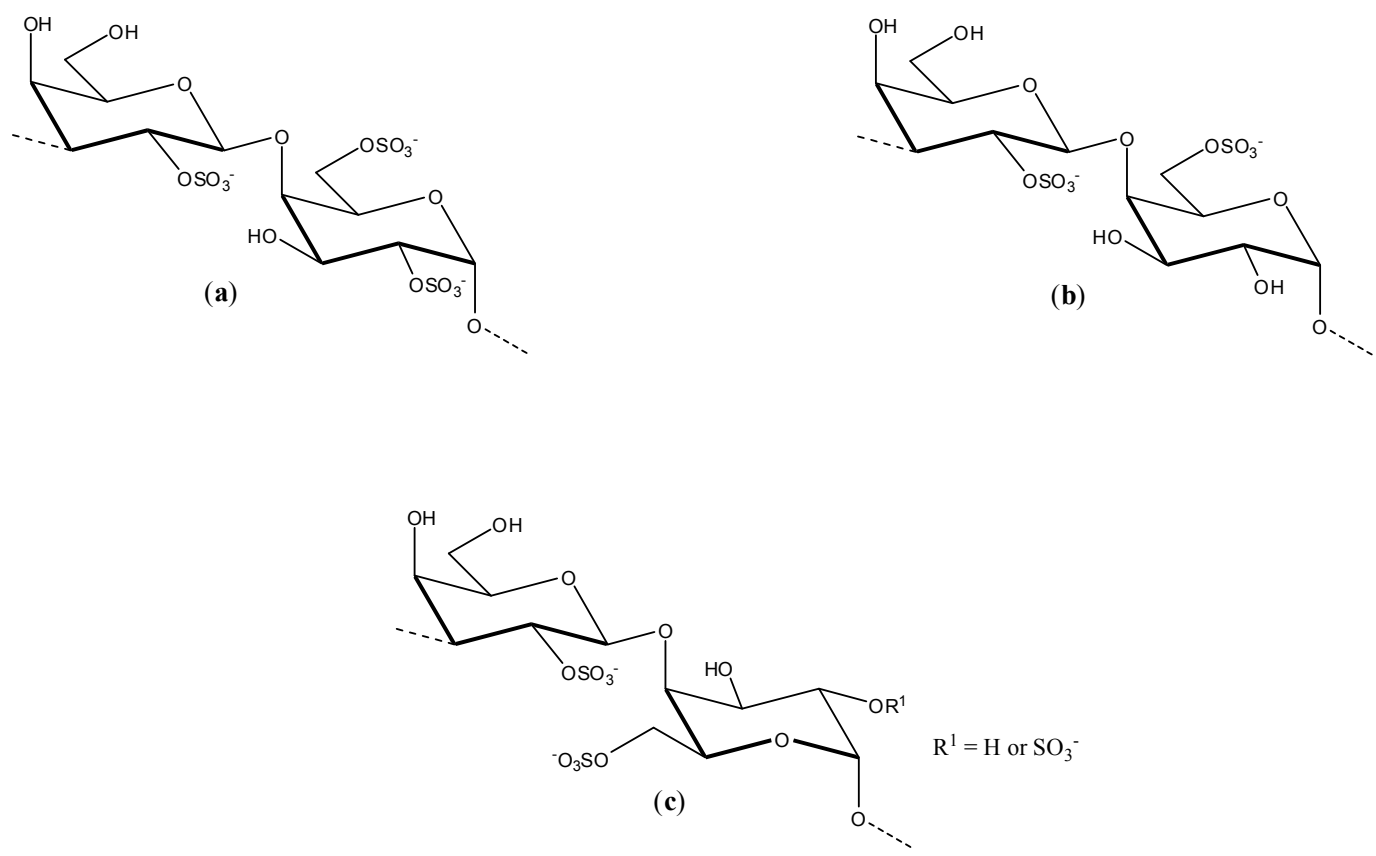

The antiviral activity evaluation of $G 3 d$ and $C 2 S-3$ was conducted in vitro and it was carried out by two methods: plaque reduction and virus yield inhibition assays. It was found that the dengue antiviral activity of sulfated $G 3 d$ and $C 2 S-3$ polysaccharides depends on both virus serotype and the host cell. Both compounds were capable of inhibiting DENV-2 in Vero cells with $\mathrm{IC}_{50}$ values for the inhibitory activity close to $1 \mu \mathrm{g} / \mathrm{mL}$ and selectivity indexes superior to 1,000 . The compounds were completely ineffective against DENV-1 and their inhibitory activity on DENV-3 ( $\mathrm{IC}_{50}$ ranging from $13.9-14.2 \mu \mathrm{g} / \mathrm{mL}$ ) and DENV-4 ( $\mathrm{IC}_{50}$ ranging from 29.3 to $>50 \mu \mathrm{g} / \mathrm{mL}$ ) were significantly lower. The inhibitory effects of $G 3 d$ and $C 2 S-3$ against DENV-2 and DENV-3 were also evaluated with respect to human HepG2 and foreskin PH cells as well as mosquito C6/36 HT cells. While the polysaccharides were totally ineffective against mosquito cells, the effectiveness of the substances with respect HepG2 and PH cells were similar to that observed with Vero cells. From the mechanism of action standpoint, it was determined that $G 3 d$ and $C 2 S-3$ present inhibitory effects on DENV-2 serotype only when they are added together with the virus or early after infection. Therefore, the processes of virus adsorption and internalization are the main targets of these compounds. The results suggest that these compounds act on virus binding. These polysaccharides may be useful tools to elucidate the mechanisms of binding and internalization of DENV serotypes to vertebrate and invertebrate cells, and also to establish structure-activity relationships [39].

Another study involving sulfated polysaccharides showed that the extracts and carrageenans derived from Meristiella gelidium were more effective inhibitors of DENV-2 compared to those derived from G. griffithsiae. The antiviral property evaluation was performed in vitro using Vero cells and virus 
plaque reduction assay. In this investigation, no description on the mechanism of action for DENV inhibition was reported [40].

A series of DL-galactan hybrids isolated from the red seaweed Gymnogongrus torulosus was assessed in vitro against DENV-2 serotype by virus reduction assay in Vero cells [41]. The repeating disaccharide units and the percentage of them found in the composition of the polysaccharides are presented in Table 2. Structures of agarose and Yaphe repeating units are shown in Figure 6.

Table 2. DL-galactan hybrids from $G$. torulosus and their $\mathrm{IC}_{50}$ values when the galactans were evaluated against DENV-2 virus serotype.

\begin{tabular}{|c|c|c|c|c|c|c|}
\hline \multirow{2}{*}{ Polyssacharide } & \multirow{2}{*}{$\begin{array}{c}\text { MW } \\
\text { (kDa) }\end{array}$} & \multicolumn{4}{|c|}{ Galactan Structure } & \multirow{2}{*}{$\begin{array}{c}\mathrm{IC}_{50} \\
(\mu \mathrm{g} / \mathrm{mL})^{\mathrm{c}}\end{array}$} \\
\hline & & Kappa/iota $^{\text {b }}$ & $\mathbf{m u} / \mathbf{n u}{ }^{\mathrm{b}}$ & Agarose $^{b}$ & Yaphe $^{\text {b }}$ & \\
\hline $\mathrm{C} 1$ & 44 & 57 & 10 & 19 & 12 & $1.1 \pm 0.2$ \\
\hline $\mathrm{C} 2$ & 56 & 1845 & 18 & 22 & 12 & $0.7 \pm 0.2$ \\
\hline $\mathrm{C} 3$ & 77 & 28 & 21 & 31 & 14 & $0.34 \pm 0.06$ \\
\hline $\mathrm{C} 4$ & 18 & 54 & 6 & 7 & 17 & $0.19 \pm 0.03$ \\
\hline F1 & 56 & 76 & - & 19 & 12 & $0.5 \pm 0.2$ \\
\hline $\mathrm{F} 2$ & 77 & 73 & 12 & 12 & - & $0.8 \pm 0.1$ \\
\hline F3 & 18 & 34 & - & 12 & 51 & $0.9 \pm 0.2$ \\
\hline F3T2 & 35 & 62 & - & 32 & 20 & $0.25 \pm 0.09$ \\
\hline F3T4 & 45 & 38 & 12 & 40 & 9 & $0.34 \pm 0.02$ \\
\hline F3T6 & 22 & 17 & 8 & 8 & 59 & $1.7 \pm 0.1$ \\
\hline
\end{tabular}

${ }^{\mathrm{a}}$ Average number molecular weight. ${ }^{\mathrm{b}}$ Approximately percentage. ${ }^{\mathrm{c}}$ Inhibitory concentration required to reduce plaque number in Vero cells by $50 \%$. Values are the mean of two determinations \pm standard deviation

Figure 6. Agarose and Yaphe repeating units found in DL-galactan hybrids isolated from the red seaweed G. torulosus.

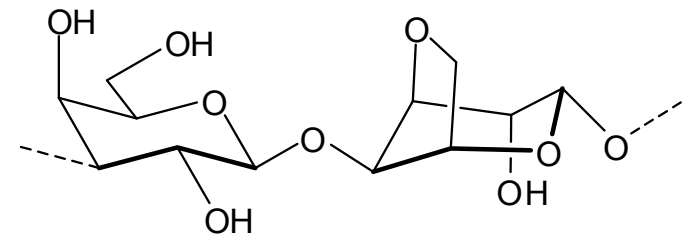

Agarose

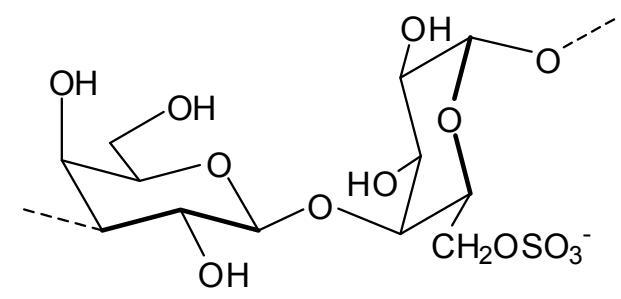

Yaphe

As can be seen in Table 2, the evaluated polysaccharides were very active against DENV-2 serotype with $\mathrm{IC}_{50}$ ranging from $0.19-1.7 \mu \mathrm{g} / \mathrm{mL}$. In addition to their inhibitory activity, the compounds did not present cytotoxic effects on stationary or on actively dividing cells, and they presented anticoagulant properties. It is suggested that the mechanism of action of these compounds corresponds to interference in the binding of the surface glycoprotein with the cell receptor [41].

One aspect deserves comment at this point. Liang and co-workers prepared sulfated agarose, sulfated kappa-carrageenan, desulfated kappa-carrageenan, and kappa-carrageenan oligosaccharides to investigate their anticoagulant and cytotoxic activities. They found that anticoagulant activity and effects on cell proliferation are both dependent on the substitution position rather than the degree of 
sulfate group substitution. Moreover, these activities are dependent on the secondary structures of polysaccharides. The investigation led to the conclusion that carrageenan and agarose can be considered for biomedical applications after careful tailoring of sulfate groups [42].

The plant storage polysaccharides known as galactomannans are characterized by a main chain of $\beta$-D-mannopyranosyl residues linked by positions 1 and 4 with single unit $\alpha$-D-galactopyranosyl side-chain-residues (Figure 7). The mannose/galactose ratio depends on either the plant source or the extraction method used $[43,44]$.

Figure 7. Basic structure of galactomannans.

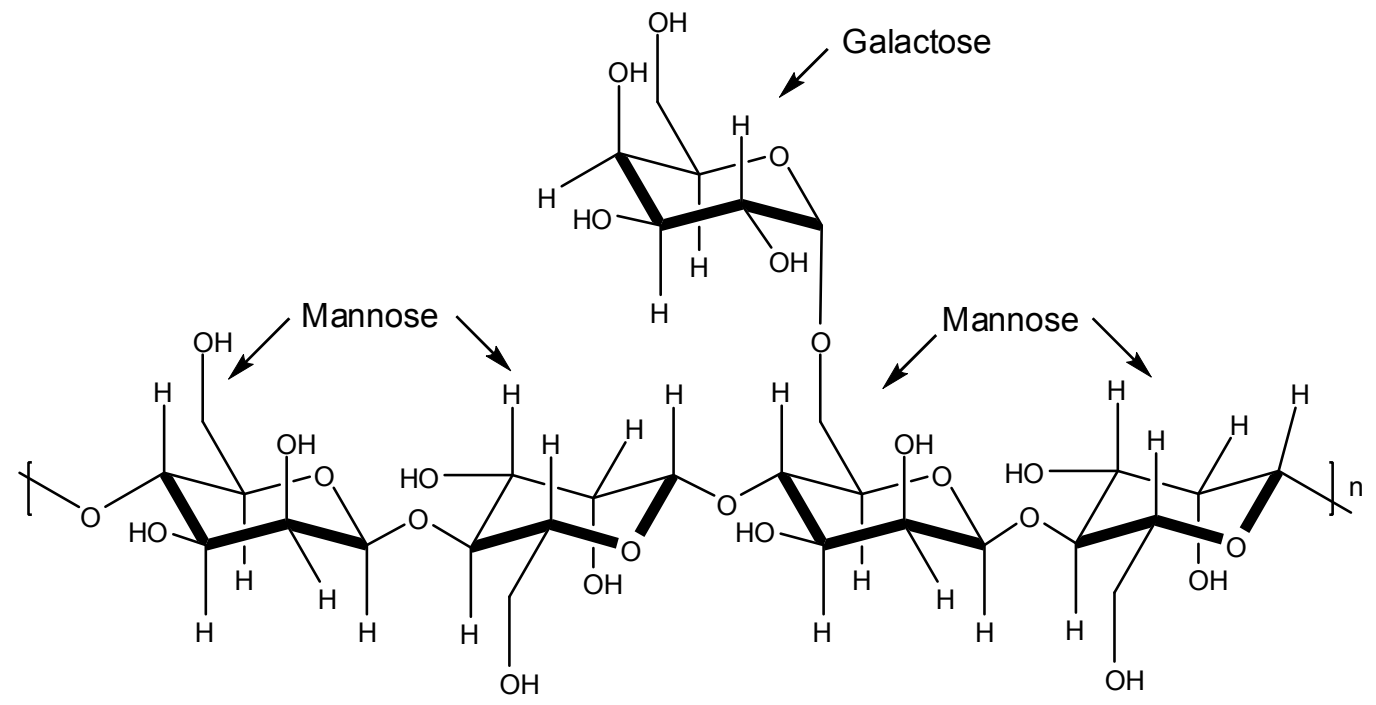

Ono and co-workers isolated two sulfated galactomannans [45]. One was isolated from the seeds of Mimosa scabrella presenting a mannose/galactose ratio of 1.1 and the other was obtained from the seeds of Leucaena leucocephala (mannose/galactose ratio of 1.4). These sulfated polysaccharides named by the authors as BRS (from M. scabrella) and LLS (from L. leucocephala) were submitted to in vitro and in vivo assays to assess their effects on DENV-1 (Hawaii strain) virus. The in vivo assay was carried out with female mice to determine antiviral activity. The in vitro evaluation was conducted with C6/36 cells by virus plaque reduction. Death of DENV-1-infected mice was not noticed. For the in vitro assay, it was found that the concentrations that produced a 100 -fold decrease in virus titer were $347 \mathrm{mg} / \mathrm{L}$ and $37 \mathrm{mg} / \mathrm{L}$ for BRS and LLS, respectively [45].

\section{Flavonoids}

Several flavonoids have been screened for dengue antiviral activity. Figure 8 shows the structures of members of this class of compounds 5-9, isolated from Mexican Tephrosia species. Their antiviral activity was evaluated in vitro by the plaque assay using LLC-MK 2 cells and DENV-2 serotype. Of the five flavonoids tested, only glabranine (5) and 7-O-methylglabranine (6) showed significant inhibitory activity (they presented $70 \%$ virus infection inhibition at $25 \mu \mathrm{mol} / \mathrm{L}$ ). No $\mathrm{IC}_{50}$ values were reported. The other flavonoids 7-9 had no antiviral effect. Considering the structures of compounds $\mathbf{5 - 9}$, it is evident that a relationship exists between the structure and antiviral activity of the investigated 
flavonoids since glabranine (5) and 7-O-methylglabranine (6), which both contain a prenyl side-chain at C-8, were active as replication inhibitors [46].

Figure 8. Structures of flanovoids from Mexican Tephrosia species

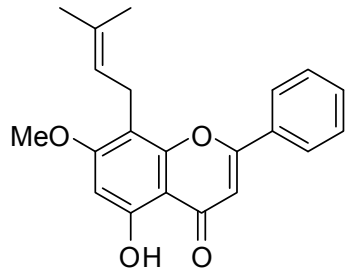

(5)

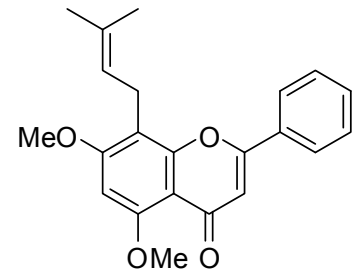

(6)

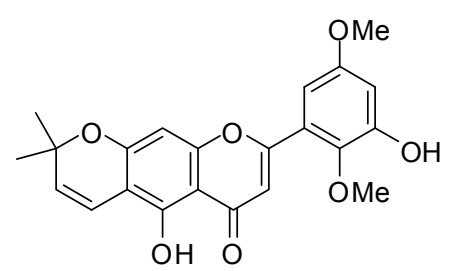

(7)

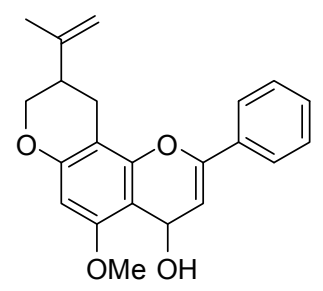

(8)

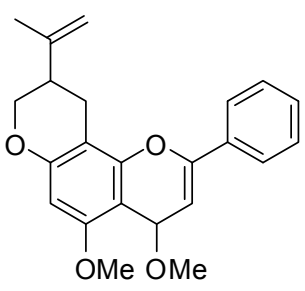

(9)

The aqueous extract of Houttuynia cordata, a popular side dish vegetable consumed in Northern and Eastern regions of Thailand, was tested against DENV-2 [47]. The assays to evaluate antiviral aqueous activity were performed in vitro in three different modes: (i) protective, (ii) treatment, and (iii) direct blocking in HepG2 and LLC-MK 2 cells. For (i) and (ii) the experiments were conducted using plaque titration assay, and for (iii) it was performed using plaque reduction assay. Considering HepG2 cells, $H$. cordata aqueous extract displayed an inhibitory effect to DENV-2 RNA production in all experimental modes. The experiments were conducted at $10 \mu \mathrm{g} / \mathrm{mL}$ and $100 \mu \mathrm{g} / \mathrm{mL}$. The higher concentration was effective to: (a) protect HepG2 cells from DENV-2 infection (protective mode); (b) decrease the intracellular viral RNA synthesis (treatment mode); (c) to inactivate the virus (direct blocking). The greatest inhibitory effect was observed in the protective mode. For LLC-MK 2 cells, the experiments were conducted within $10-40 \mu \mathrm{g} / \mathrm{mL}$ concentration range, and the aqueous extract also exhibited a protective effect on virion release. High Performance Liquid Chromatography (HPLC) analysis identified the flavonoid hyperoside (10) as the major component of the extract (Figure 9). It is very likely that the observed dengue antiviral activity is associated with the presence of this flavonoid as the major component in the aqueous extract. The extract also protects the cells from viral entry and inhibits virus activities after adsorption. In the treatment mode, hyperoside (10) in the extract probably inhibited intracellular RNA synthesis by interacting with enzymes or proteins in the viral replication complex [47]. Apparently pure hyperoside-even though quite readily available from many plants- has not been tested as an isolated compound.

Boesenbergia rotunda (L.) is a common spice belonging to the ginger family (Zingiberaceae). Figure 10 depicts the structures of the flavonoids pinostrobin (11), pinocembrin (12), alpinetin (13), the phenylpropanoid cardamonin (14), and the cyclohexenylchalcone derivatives pandurantin A (15) and 4-hydroxypanduratin A (16), all of them isolated from the aforementioned vegetal species [48]. 
Figure 9. Structure of hyperoside (10).<smiles></smiles>

Figure 10. Structures of compounds 11-16.<smiles>[R]c1cc([R])c2c(c1)OC(c1ccccc1)CC2=O</smiles>

$\mathrm{R}=\mathrm{OMe}, \mathrm{R}^{\prime}=\mathrm{OH}:$ Pinostrobin (11)

$\mathrm{R}=\mathrm{OH}, \mathrm{R}^{\prime}=\mathrm{OH}:$ Pinocembrin (12)

$\mathrm{R}=\mathrm{OH}, \mathrm{R}^{\prime}=\mathrm{OMe}$ : Alpinetin (13)<smiles>COc1cc(O)cc(O)c1C(=O)/C=C/c1ccccc1</smiles>

Cardamonin (14)

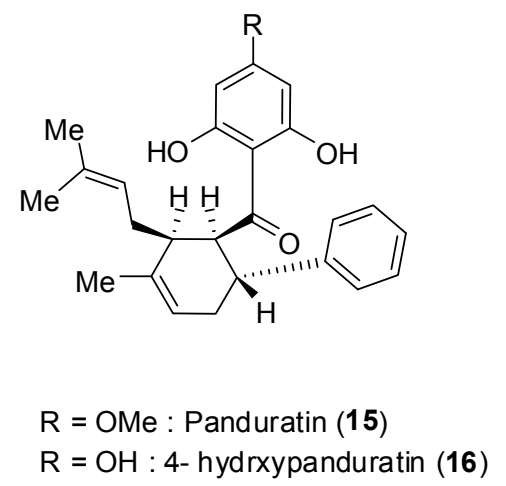

These natural products were screened against DENV-2 virus NS2B-NS3 protease by enzyme assay. The assay was performed with the purified protease [48]. Increased concentration of the compounds led to increase inhibition of enzyme activity. Among the compounds, pinocembrin (12) was the least active inhibiting by about $60 \%$ at $400 \mathrm{ppm}$ concentration. The most active substances corresponded to panduratin A (15) and 4-hydroxypanduratin B (16), and their inhibitory protease activities are presented in Table 3.

Table 3. Percentage inhibition of DENV-2 NS2B-NS3 virus protease cleavage ${ }^{\text {a }}$ of compounds 15 and 16.

\begin{tabular}{cccccccc}
\hline \multirow{2}{*}{ Compound } & \multicolumn{6}{c}{ Percentage Inhibition of DENV-2 NS2B-NS3 Protease; Concentration Used (ppm) } \\
\cline { 2 - 7 } & $\mathbf{4 0}$ & $\mathbf{8 0}$ & $\mathbf{1 2 0}$ & $\mathbf{1 6 0}$ & $\mathbf{2 4 0}$ & $\mathbf{4 0 0}$ \\
\hline 15 & $27.1 \pm 4.8$ & $66.7 \pm 0.1$ & $87.7 \pm 0.6$ & $93.7 \pm 0.5$ & $92.2 \pm 1.2$ & $99.8 \pm 1.1$ \\
16 & $52.0 \pm 1.1$ & $78.1 \pm 0.1$ & $87.6 \pm 0.4$ & $96.0 \pm 0.5$ & $97.3 \pm 0.3$ & $99.8 \pm 0.3$ \\
\hline
\end{tabular}

${ }^{\mathrm{a}}$ The substrate cleaved by NS3 protease used in the experiment corresponded to the peptide Boc-Gly-ArgArg-MCA. \pm corresponds to standard deviation. 
Interestingly, although the compounds $\mathbf{1 2}$ and $\mathbf{1 4}$ had low inhibitory activity on NS2B-NS3 protease, some synergistic effect was noticed when these compounds were mixed (Table 4).

Table 4. Percentage inhibition of DENV-2 NS2B-NS3 virus protease cleavage ${ }^{\text {a }}$ of compounds and 12 and 14.

\begin{tabular}{cccc}
\hline \multirow{2}{*}{ Compound } & \multicolumn{3}{c}{$\begin{array}{c}\text { Percentage Inhibition of DENV-2 NS2B-NS3 Protease; } \\
\text { Concentration Used (ppm) }\end{array}$} \\
\cline { 2 - 4 } & $\mathbf{1 2 0}$ & $\mathbf{2 4 0}$ & $\mathbf{4 0 0}$ \\
\hline 12 & $30.1 \pm 0.5$ & $47.3 \pm 0.5$ & $56.1 \pm 0.4$ \\
14 & $39.4 \pm 0.6$ & $50.1 \pm 0.4$ & $71.3 \pm 0.3$ \\
$12+14$ & $52.6 \pm 0.4$ & $63.5 \pm 0.5$ & $81.8 \pm 0.3$ \\
\hline
\end{tabular}

a The substrate cleaved by NS2B-NS3 protease protease used in the experiment corresponded to the peptide Boc-Gly-Arg-Arg-MCA. \pm corresponds to standard deviation.

For the most active compounds $\mathbf{1 5}$ and 16, it was determined that they present competitive inhibitory activity on NS2B-NS3 displaying inhibitory constants $\left(K_{i}\right)$ of 21 and $25 \mu \mathrm{mol} / \mathrm{L}$, respectively.

The flavonoids quercetin (17), naringenin (18) daidzein (19), and hesperetin (20) (Figure 11) were evaluated against DENV-2 serotype by Zandi and co-workers. The assessment of antiviral activity was conducted in vitro utilizing Vero cells. DENV replication was measured by Foci Forming Unit Reduction Assay (FFURA) and quantitative real time polymerase chain amplification (qRT-PCR). [49]. Of these compounds, only quercetin (17) presented significant inhibitory activity $\left(\mathrm{IC}_{50}\right.$ was $35.7 \mu \mathrm{g} / \mathrm{mL}$ ) against DENV-2 infection in Vero cells. The selective index for quercetin when the infected cells were treated or when uninfected cells were treated continuously $5 \mathrm{~h}$ before infection until 4 days post infection were 7.07 and 8.74, respectively. The mechanism by which quercetin exerts its antiviral effect remains unknown. However, it is believed that DENV antiviral activity of $\mathbf{1 7}$ could be similar to that presented by others flavonoids that act against cellular RNA polymerases and formation of the complex with RNA [49].

Figure 11. Structures of compounds 17-20.<smiles>O=c1c(O)c(-c2ccc(O)c(O)c2)oc2cc(O)cc(O)c12</smiles>

(17)<smiles>O=c1c(-c2ccc(O)cc2)coc2cc(O)ccc12</smiles>

(19)<smiles>O=C1C[C@H](c2ccc(O)cc2)Oc2cc(O)cc(O)c21</smiles>

(18)<smiles>COc1ccc([C@H]2CC(=O)c3c(O)cc(O)cc3O2)cc1O</smiles>

(20) 
The study of Zandi and co-workers evaluated the effects of naringenin (18) (Figure 11), rutin (21), and fisetin (22) (Figure 12) against DENV-2 (NGC strain). Antiviral effects of each compound at the different stages of DENV-2 infection were examined in vitro using FFURA and qRT-PCR. The authors found that among the flavonoids studied only $\mathbf{2 2}$ presented significant in vitro activity on dengue virus replication activity [50]. Compound 22 did inhibit virus replication $\left(\mathrm{IC}_{50}\right.$ of $55 \mu \mathrm{g} / \mathrm{mL}$ and selectivity index of 4.49) after virus adsorption on Vero cells. When Vero cells were continuously treated for $5 \mathrm{~h}$ before virus infection and continuously up to 4 days post-infection, $\mathrm{IC}_{50}$ corresponded to $43.12 \mu \mathrm{g} / \mathrm{mL}$ and selective index of 5.72. The authors report that no virucidal or prophylactic activity was noticed for fisetin (22). Even though compounds 18 and 21 did not inhibit DENV-2 replication, flavonoid 18 displayed virucidal activity $\left(\mathrm{IC}_{50}\right.$ of $52.64 \mu \mathrm{g} / \mathrm{mL}$ ), albeit with a low selectivity index $(<1)$. The mechanism of how fisetin affects DENV virus replication is unclear. For the authors, it is not likely to act directly on the virus, because it does not affect DENV-2 binding to cells. They believe that fisetin (22) could affect DENV genome copy number by interference in DENV-2 replication (by binding directly to virus RNA or forming a flavonoid-RNA complex) or by affecting the RNA polymerases resulting in inhibition of virus replication [50].

Figure 12. Structures of rutin (21) and fisetin (22).
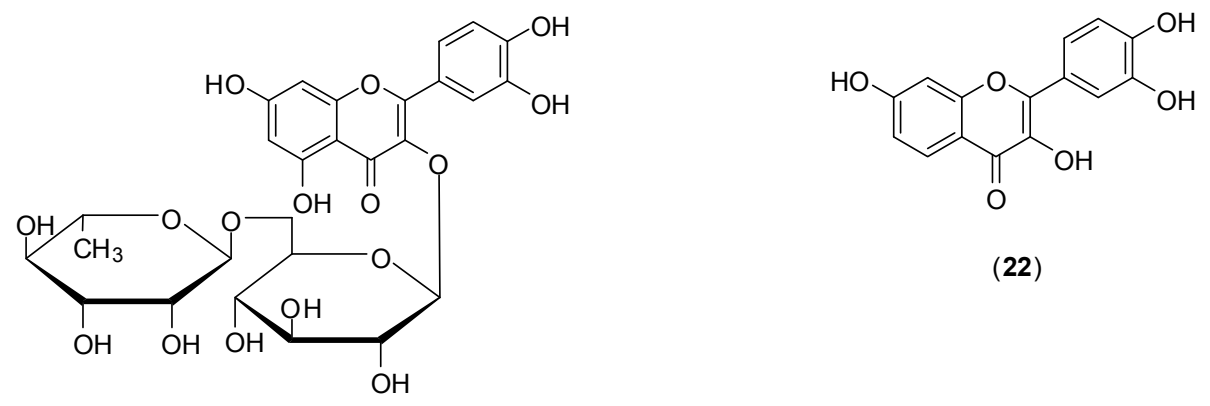

(22)

(21)

A biological screening conducted on 1,350 ethyl acetate extracts prepared from various parts of approximately 650 New Caledonian plants was carried out targeting the DENV-2 NS5 polymerase. Enzyme assays were performed. DENV-2 NS5 polymerase genes were tagged by six N-terminal histidine residues and expressed from the pQE30 vector (Qiagen, Venlo, Limburg, Netherlands) in E. coli Rosetta pLacI cells (Novagen, Darmstadt, Germany). The enzymes were produced and purified by Heparin-Sepharose Chromatography. Alternatively, gel filtration was used as a second purification step.

Polymerase activity was assayed by monitoring the incorporation of radiolabeled guanosine into a homopolymeric cytosine RNA template. Among several active extracts, the very active one from the bark of Cryptocarya chartacea Kostern, a species belonging to the Lauraceae family [51] was selected. From the selected extract, it was isolated the non-alkylated flavonoid pinocembrin (12) as well as series of new mono and dialkylated ones named chartaceones A-F (23-32, Figure 13). The screening of compounds 23-32 against DENV-2 NS5 polymerase showed that the chartaceones C-F (compounds 29-32) were the most active in inhibiting polymerase activity ( $\mathrm{IC}_{50}$ ranging from 1.8 to $4.2 \mu \mathrm{mol} / \mathrm{L}$ ) while the other chartaceones were less effective. On the contrary, compound $\mathbf{1 2}$ was completely inactive. These findings suggest that the presence of alkylated chains in the structures of chartaceones $\mathrm{C}-\mathrm{F}$ (29-32) play important role in terms of inhibitory activity on DENV-2 NS5 polymerase. The 
compounds 12, 23-33 were also screened against bovine diarrhea virus (BVDV) NS5 polymerase and no activity was observed. Therefore, it seems that these natural substances present some selectivity towards DENV2-NS5 polymerase. Considering that the activity of compounds 29-32 against DENV-2 NS5 polymerase was similar, it was concluded that side chains A and B (Figure 13) play an equivalent role in terms of biological activity [51]. Figure 14 shows the structures of the last two compounds discussed in this section.

Figure 13. Structures of pinocembrin and chartaceones.<smiles>[R]c1c([R])c2c(c(O)c1O)C(=O)C[C@H](c1ccccc1)O2</smiles>

Pinocembrin (12):

Chartaceone A (23): $\mathrm{R}^{1}=\mathrm{A}, \mathrm{R}^{2}=\mathrm{H}$

Chartaceone A1 (24): $2 R, 5 " R$

Chartaceone A2 (25): $2 R, 5 " S$

Chartaceone A3 (26): 2S, 5"R

Chartaceone A4 (27): 2S, 5"S

Chartaceone B (28): $\quad R^{1}=B, R^{2}=H$

Chartaceone C (29): $\quad R^{1}=R^{2}=B$

Chartaceone D (30): $\quad R^{1}=B, R^{2}=A$

Chartaceone $E$ (31): $\quad R^{1}=A, R^{2}=B$

Chartaceone $F \quad(32): \quad R^{1}=R^{2}=A$<smiles>CC(C)CCCC(=O)O</smiles><smiles>[B]c1ccc(C(C)C=CCCCC(=O)O)cc1</smiles>

Figure 14. Structures of compounds 33-35.<smiles>O=c1cc(-c2ccccc2)oc2cc(O)c(O)c(O)c12</smiles>

(33)

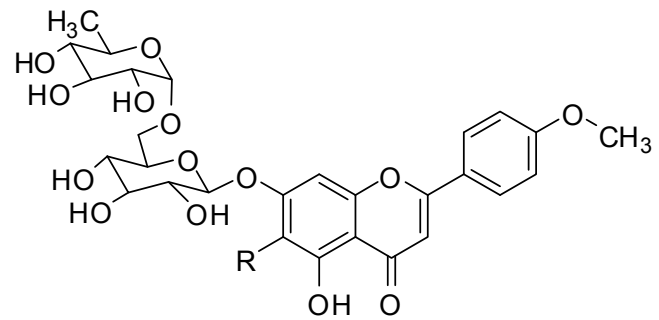

(34) $\mathrm{R}=\mathrm{OCH}_{3}$ (35) $\mathrm{H}$

Scutellaria baicalensis is a tradicional Chinese medicinal herb belonging to the Lamiaceae family. From the roots of this species, baicalein (33) is usually extracted [52]. The authors conducted in vitro assay using Vero cells an FFURA to assess antiviral activity against DENV-2. This flavonoid inhibited DENV-2 serotype replication in Vero cells displaying an $\mathrm{IC}_{50}$ of $6.46 \mu \mathrm{g} / \mathrm{mL}$ and a selectivity index of 17.8 when it was added after adsorption to the cells. The $\mathrm{IC}_{50}$ against DENV-2 is $5.39 \mu \mathrm{g} / \mathrm{mL}$ and the selectivity index increased to 21.3 when Vero cells were treated before virus infection and continuously up to 4 days post-infection. Substance $\mathbf{3 3}$ displayed direct virucidal ( $\mathrm{IC}_{50}$ of $1.55 \mu \mathrm{g} / \mathrm{mL})$ as well as anti-adsorption $\left(\mathrm{IC}_{50}\right.$ of $\left.7.14 \mu \mathrm{g} / \mathrm{mL}\right)$ effects against DENV-2. The results suggest that a possible mechanism for the extracellular and intracellular activities of baicalein (33) against DENV-2 could be attributed to its ability to bind and/or to inactivate important structural and/or non-structural protein(s) of DENV-2 [52]. 
A phytochemical investigation of the ethanol extracts from Distictella elongate (Vahl) Urb led to isolation of petcolinarin (34) from the leaf extract and a mixture of $\mathbf{3 4}$ and acacetin-7-O-rutinoside (35) from fruit extract. In vitro MTT colorimetric assays, using Vero and LLCMK2 cells, were conducted to assess antiviral activity against DENV-2. The mixture of $\mathbf{3 4}$ and $\mathbf{3 5}$ presented better anti-DENV-2 activity $\left(\mathrm{EC}_{50}\right.$ of $11.1 \pm 1.6 \mu \mathrm{g} / \mathrm{mL}$ and selectivity index $\left.>45\right)$ than pure petcolinarin $(34)\left(\mathrm{EC}_{50}\right.$ of $86.4 \pm 3.8 \mu \mathrm{g} / \mathrm{mL}$ and selectivity index of 4.6). The mechanism of inhibition of the compounds is unclear, but it is suggested that it may correspond to one of the putative mechanisms already described for flavonoids [53].

\section{Alkaloids and Related Compounds}

Emetine (36, Figure 15) is a compound belonging to the ipecacuanha alkaloids. Its dihydrochloride was identified by Low and co-workers as a compound displaying potent DENV antiviral activity at a very low concentration of $0.5 \mu \mathrm{mol} / \mathrm{L}(277 \mathrm{ng} / \mathrm{mL})$ [54]. The investigators conducted in vitro experiments using Huh-7 and BHK21 cells via viral plaque assay associated with immunofluorescence assay and qRT-PCR. A series of experiments led to the conclusion that emetine dihydrochloride acts inhibiting DENV infection at the early stages of viral replication life cycle, either affecting the viral RNA synthesis pathway or viral protein translation pathway.

Figure 15. Structures of alkaloids 36-38.
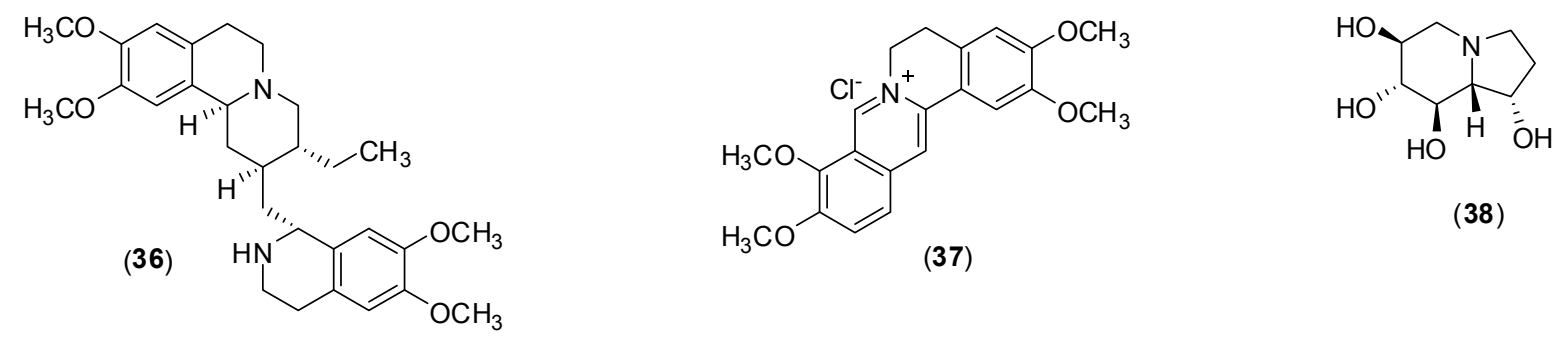

(38)

Coptis chinensis Franch is a medicinal plant used in China to treat bacterial, inflammatory, fungal and other diseases, presenting no significant side effects or toxicity to humans at clinical doses [55]. This vegetal species presents a high concentration of palmatine (37, Figure 15) which was screened in vitro for its antivirus activity against DENV-2 using Vero cells via viral titer reduction assays. Vero cells were infected with DENV-2 and the $\mathrm{EC}_{50}$ was estimated to be $26.4 \mu \mathrm{mol} / \mathrm{L}$ and the selectivity index to be 39. In the same work, the authors demonstrated in an enzyme assay that palmatine (37) could inhibit the NS2B-NS3 protease of West Nile Virus (WNV). The mechanism by which alkaloid 37 inhibits the virus is not clear yet; the authors of this investigation plan to clarify the mechanism of action mainly based on a viral reverse genetics system, virus-encoded proteases and selection and characterization of palmatine-resistant viruses [55].

The water soluble castanospermine (38), Figure 15, is derived from Castanospermum australe (black bean or Moreton Bay chestnut tree). An in vitro and in vivo experiments were conducted to ascertain whether this alkaloid can inhibit all dengue virus serotypes. The in vitro experiment used to investigate antiviral activity used BHK-21 cells in a plaque reduction assay and was verified with western blotting, ELISA and fluorogenic RT-PCR. In vivo experiment was also conducted with A/J mice (28 to 31 days old). Alkaloid 38 inhibits all dengue virus serotype infections in vitro and dengue 
virus serotype 2 in vivo. It was found that inhibition occurs at the level of secretion and infectivity of viral particles. Additionally, castanospermine (38) prevented mortality in a mouse model of dengue virus infection, with doses of 10,50 , and $250 \mathrm{mg} / \mathrm{kg}$ of body weight per day being highly effective at promoting survival [56].

The aminoglycoside geneticin (39, Figure 16) presents antiviral activity against bovine viral diarrhea virus (BVDV). Taking into consideration that dengue virus, yellow fever virus and BVDV are in the Flaviviradae family, Zhang and co-workers undertook the task of screening 39 against dengue virus.

Figure 16. Structure of the aminoglycoside geneticin (39).<smiles>C[C@H](O)[C@]1(O)O[C@H](O[C@@H]2[C@@H](N)C[C@@H](N)[C@H](O[C@@H]3OC[C@@](C)(O)[C@H](N)[C@H]3O)[C@H]2O)[C@H](N)[C@@H](O)[C@@H]1O</smiles>

The antiviral activity was assessed in vitro with BHK cells by viral plaque reduction assay with western blotting and qRT-PCR. The results demonstrated that compound 39 inhibits DENV-2 proliferation by: (i) protecting $\mathrm{BHK}$ cells against the cytopathic effect of DENV-2 $\left(\mathrm{EC}_{50}\right.$ of $3 \pm 0.1 \mu \mathrm{g} / \mathrm{mL}$ for this activity); (ii) reducing the viral yield $\left(\mathrm{EC}_{50}\right.$ of $2 \pm 0.1 \mu \mathrm{g} / \mathrm{mL}$ and $\mathrm{EC}_{90}$ of $20 \pm 2 \mu \mathrm{g} / \mathrm{mL}$ ); (iii) inhibiting DENV-2 plaque formation in both the number and the size of the plaques ( $\mathrm{EC}_{90}$ of $25 \mu \mathrm{g} / \mathrm{mL}$ ); (iv) blocking DENV-2 RNA and protein synthesis. It was also found that the selectivity index of $\mathbf{4 0}$ was equal to 66 [57]. While compound $\mathbf{4 0}$ was active against DENV-2, no inhibition was observed on yellow fever virus in the screening with BHK cells. The molecular mechanism of antiviral activity of geneticin (40) remains unclear. The results suggest that the geneticin-mediated antiviral mechanism is cell type-independent [57].

\section{Terpenoids}

The bark and the wood of Trigonostemon cherrieri, a rare plant of New Caledonia, were investigated for their chemical composition resulting in the isolation and characterization of several oxygenated terpenes, among them compounds 40-42 (Figure 17).

The compounds were evaluated for the ability to interfere with NS5 DENV polymerase by an enzyme assay with purified enzyme. All of them indeed presented inhibitory effects on enzyme activity with the $\mathrm{IC}_{50}$ of $12.7 \pm 0.2,3.1 \pm 0.2$ and $16.0 \pm 1.3 \mu \mathrm{mol} / \mathrm{L}$ for compounds $\mathbf{4 0}, \mathbf{4 1}$, and $\mathbf{4 2}$, respectively. There is no report on the mechanism of inhibition of the compounds [58]. 
Figure 17. Structures of terpenes 40, 41 and $\mathbf{4 2 .}$

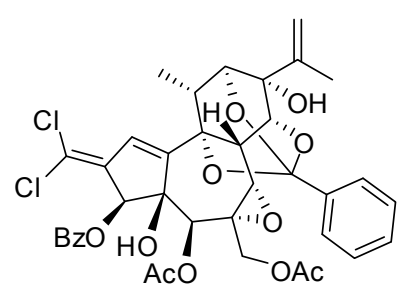

(40)

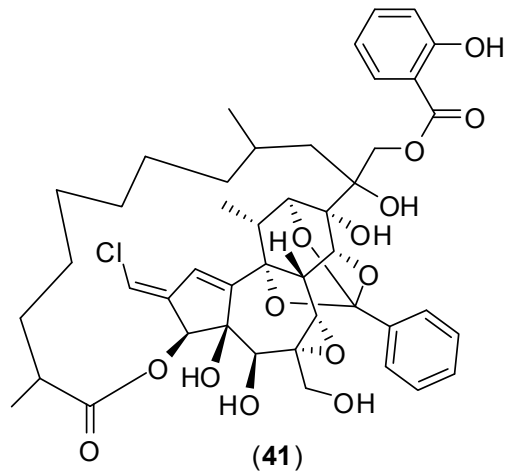

(41)

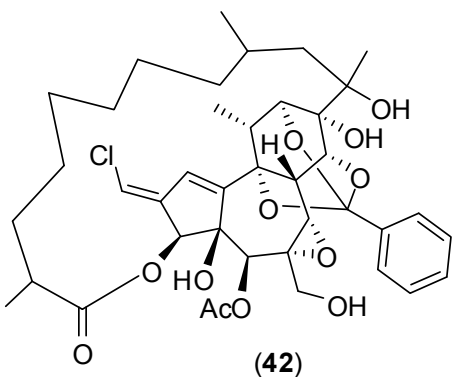

(42)

A bioguided investigation aimed to obtain antiviral chemical constituents from an ethanol extract of leaves from Arrabidaea pulchra resulted in the isolation of triterpene compound $\mathbf{4 3}$ along with phenolic derivatives 44 and 45 (Figure 18).

Figure 18. Structure of terpenoid 43 and phenolic compounds 44 and 45.

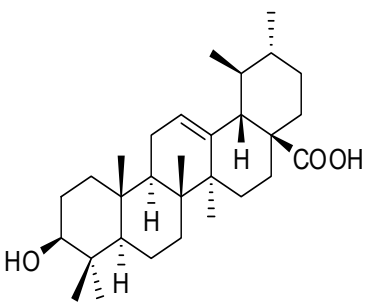

(43)

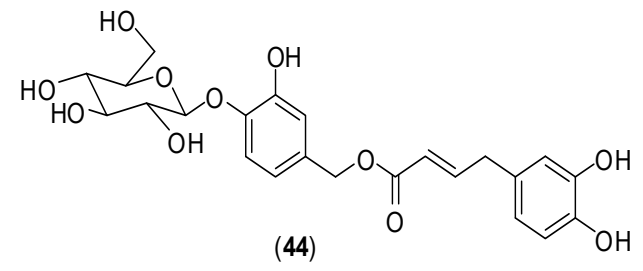

$(44)$

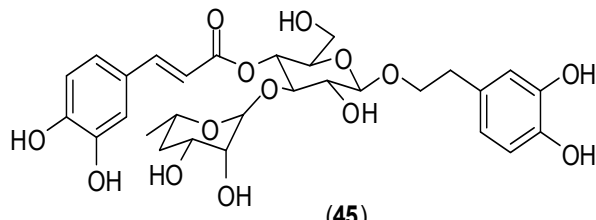

(45)

The isolated compounds displayed activity against DENV-2. Cytotoxity was determined in vitro against $\mathrm{LLCMK}_{2}$ and Vero cells by MTT colorimetric assay. The determined $\mathrm{EC}_{50}$ and the selectivity indexes for the compounds were as follows: $43\left(\mathrm{EC}_{50}=3.2 \pm 0.6 \mu \mathrm{g} / \mathrm{mL}\right.$; selectivity index $\left.=3.1\right) ; 44$ $\left(\mathrm{EC}_{50}=2.8 \pm 0.4 \mu \mathrm{g} / \mathrm{mL}\right.$; selectivity index $\left.=20.0\right) ; 45\left(\mathrm{EC}_{50}=3.4 \pm 0.4 \mu \mathrm{g} / \mathrm{mL}\right.$; selectivity index $\left.=3.8\right)$. The same assay was conducted with Human Herpesvirus-1 (HSV-1), Vaccinia Virus Western Reserve (VACV-WR) and Murine Encephalomyocarditis virus (EMCV). The inhibition of HSV-1 and VACV-WR was lower than that of DENV-2, and no inhibition was observed for EMCV. Further investigations are needed to understand the mechanisms of the antiviral activity, especially for compound 45 which displayed the lowest toxicity in LLCMK2 cells and was active only against DENV-2. Further assays are also needed to investigate virucidal activity and targets in the viral replication cycle [59].

\section{Polycyclic Quinones}

The marine environment has been explored in the interests of identification of new leads for pharmaceutical purposes including antivirals [60]. The polycyclic gymnochrome D (46) and isogymnochrome D (47) (Figure 19) were isolated from the living fossil crinoids Gymnocrinus richeri [61]. The assessment of their effect on DENV-1 (strain Hawai/1944) virus was conducted in vitro using porcine PS cells in a plaque reduction assay. The results showed that they display antiviral activity. This activity was determined by the reduction of foci (RF) formed by DENV-1 compared with 
controls. Thus, for compound 46 and $\mathbf{4 7}$, the determined $\mathrm{RF}_{50}$ was smaller than $1 \mu \mathrm{g} / \mathrm{mL}$. The mechanism by which the compounds could inhibit the virus was not reported [61].

Figure 19. Structures of polycyclic quinones 46 and 47.

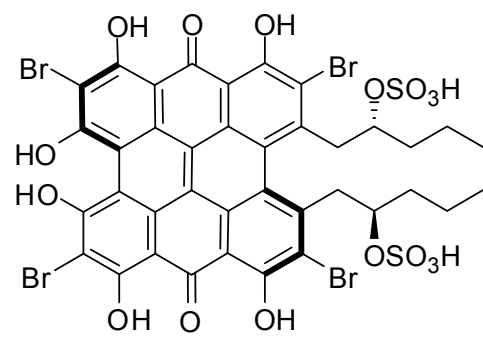

(46)

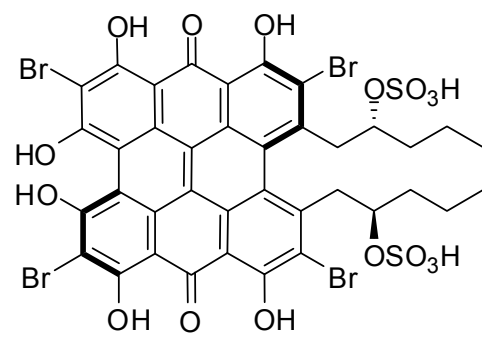

(47)

The polycyclic quinones hypericin (48), tetrabromohypericin (49) and gymnochrome B (50) (Figure 20) were also examined for both their antidengue virus activities and their photoactivities. In this investigation researchers conducted an in vitro experiment with PS cells by plaque reduction assay against dengue virus serotypes 2 and 4 . It was determined that all of these quinones presented virucidal an antiviral activities which are enhanced by light. The virucidal activity presented the following increasing order of potency: tetrabromohypericin (49) $\left(\mathrm{ED}_{50}=2.8 \mathrm{nmol} / \mathrm{mL}\right)$; hypericin $(48)\left(\mathrm{ED}_{50}=1.8 \mathrm{nmol} / \mathrm{mL}\right)$; gymnochrome B (50) $\left(\mathrm{ED}_{50}=0.042 \mathrm{nmol} / \mathrm{mL}\right)$. A similar trend was found for the antiviral effect: tetrabromohypericin (49) $\left(\mathrm{ED}_{50}=3.7 \mathrm{nmol} / \mathrm{L}\right)$; hypericin $(48)\left(\mathrm{ED}_{50}=0.6 \mathrm{nmol} / \mathrm{mL}\right)$; gymnochrome $\mathrm{B}$ (50) $\left(\mathrm{ED}_{50}=0.029 \mathrm{nmol} / \mathrm{L}\right)$. ED stands for effective dose. The tested doses ranged from 50 to $0.001 \mu \mathrm{g} / \mathrm{mL}$. Considering that the most active compound was gymnochrome B (50), it is apparent that the presence of the side chain in the structure of compound $\mathbf{5 0}$ seems to be beneficial for both virucidal and antiviral activities. [62].

Figure 20. Structures of polycyclic quinones 48,49 and 50.

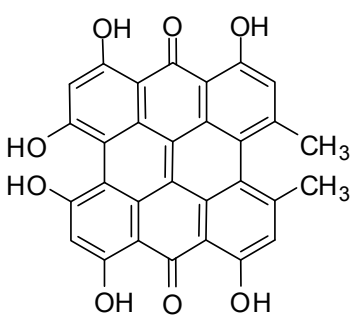

(48)

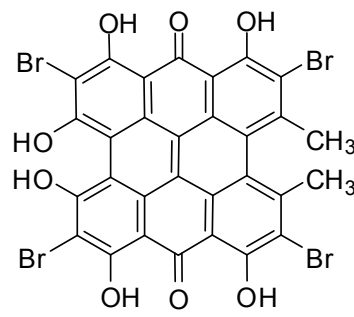

(49)

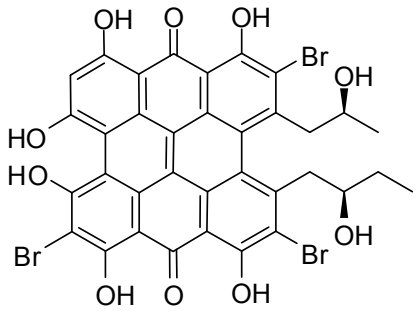

(50)

\section{Phenolics}

The screening of 850 ethyl acetate extracts of Madagascan plants was carried out resulting in the isolation of several phenolic glycosides from Flacourtia ramontchi. To assess antiviral activity, the authors conducted enzyme assays with purified enzyme NS5 polymerase of dengue virus. The substances 51 and 52 (Figure 21) were the most active phenolic derivatives evaluated against DENV NS5 polymerase. The observed activity was moderate and the determined $\mathrm{IC}_{50}$ values were 
$9.3 \pm 2.8 \mu \mathrm{mol} / \mathrm{L}$ for $\mathbf{5 1}$ and $9.5 \pm 5.0 \mu \mathrm{mol} / \mathrm{L}$ for $\mathbf{5 2}$. The mechanism of action of these compounds needs to be further investigated [63].

Figure 21. Phenolic glycosides 51 and 52.

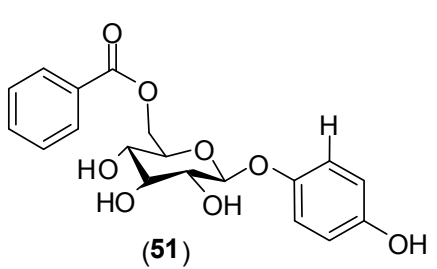

(51)

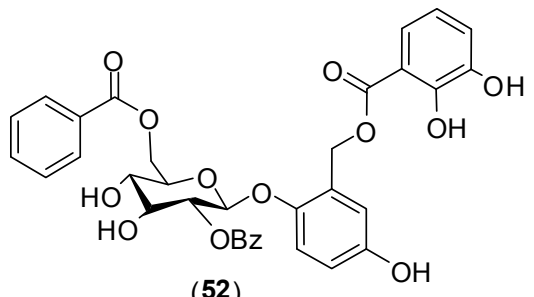

(52)

Rahman and collaborators conducted an in vitro experiment with C6/36 cells by MMT colorimetric assay against Dengue Virus serotype 2, and an enzyme assay with purified DENV-2 NS2B/3. Methyl gallate (53, Figure 22) which was purified from the methanol extract of Quercus lusitanica inhibited $98 \%$ of DENV-2 NS2B/3 protease at $0.3 \mathrm{mg} / \mathrm{mL}$. Infected and treated C6/36 cells showed that the treatment with crude methanol extracts as well as methyl gallate (53) purified from the extract down-regulated the expression of the NS1 protein. This result could be related to a reduction or absence of a cytopathic effect on infected C6/36 cells [64].

Figure 22. Structure of methyl gallate (53).<smiles>COC(=O)c1cc(O)c(O)c(O)c1</smiles>

(53)

\section{Miscellaneous}

Several other compounds (Figure 23) have been reported to possess antivirus activity. Zoasteric acid (54) is obtained from the temperate marine eelgrass, Zastera marina. Rees and collaborators conducted in vitro experiments with LLCMK-2 cells by focus forming unit reduction assay and qRT-PCR to evaluate if compound $\mathbf{5 4}$ could inhibit all serotypes of dengue virus. Compound $\mathbf{5 4}$ presented a modest antiviral activity against serotype 2 with $\mathrm{IC}_{50}$ of approximately $2.3 \mathrm{mmol} / \mathrm{L}$. This investigation also identified the synthetic analogue of zoasteric acid (55) as a more active compound concerning antidengue activity. It presented inhibitory effects against all DENV serotypes displaying $\mathrm{IC}_{50}$ of $24,46,14$ and $47 \mu \mathrm{mol} / \mathrm{L}$ against DENV-1, DENV-2, DENV-3 and DENV-4, respectively. The analogue 55 showed support of inhibition at an entry step in the viral life cycle and enhanced virus-cell binding as evidenced by a quantitative RT-PCR assay system. The idea that compound $\mathbf{5 5}$ interferes with entry by promoting inappropriate virus-cell contacts would lend support to the hypothesis that these compounds function through binding to attachment domains on adherent organisms and subsequent release from the protected surface [65]. 
Squalamine (56) was first discovered in the tissues of the dog fish shark (Squalus acanthias) and later identified within the circulating white blood cells of the sea lamprey (Petromyzon marinus). The in vitro effect of squalamine (56) on dengue virus infection of human endothelial cells (HMEC-1) was evaluated by the plaque assay. At the concentration of $40 \mu \mathrm{g} / \mathrm{mL}$, dengue infection was inhibited by $60 \%$. The infection was completely suppressed at $100 \mu \mathrm{g} / \mathrm{mL}$. The proposed mechanism of action involves the capacity of squalamine (56) to neutralize the negative electrostatic surface charge of intracellular membranes in a way that renders the cell less effective in supporting viral replication [66].

Figure 23. Structures of compounds 54-62.
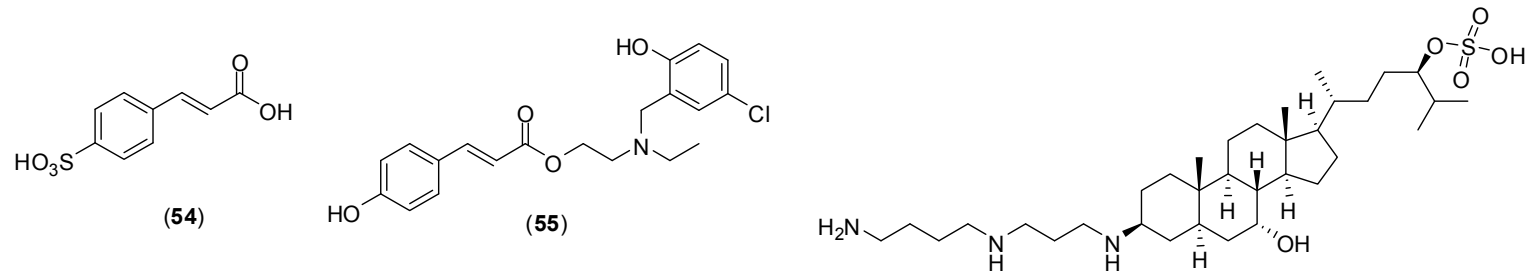

(56)

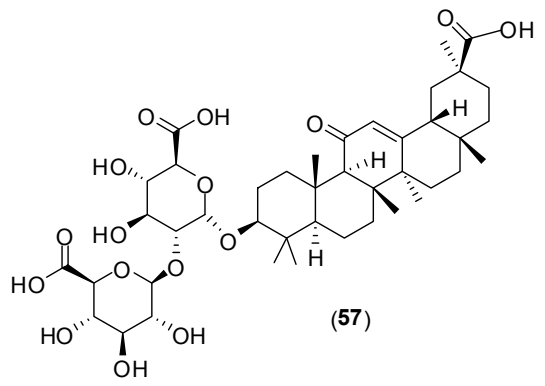

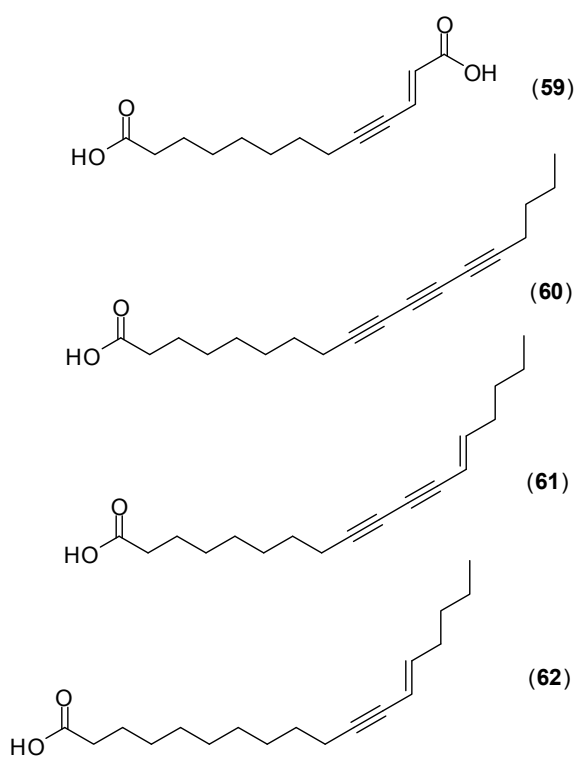

Table 5. Bioactivities determined for glycyrrhizin (58) against DENV-1-3.

\begin{tabular}{|c|c|c|c|c|}
\hline \multirow[b]{2}{*}{ Virus Serotype } & \multirow[b]{2}{*}{$\mathrm{EC}_{50}{ }^{\mathrm{a}}(\mu \mathrm{g} / \mathrm{mL})$} & \multirow[b]{2}{*}{$\mathrm{EC}_{90}{ }^{\mathrm{b}}(\mu \mathrm{g} / \mathrm{mL})$} & \multicolumn{2}{|c|}{ Selectivity Index ${ }^{c}$} \\
\hline & & & $\begin{array}{c}\text { Based on } \mathrm{CC}_{50} \\
\text { of Confluent Cells d }\end{array}$ & $\begin{array}{c}\text { Based on } \mathrm{CC}_{50} \text { for } \\
\text { Growing Cells }\end{array}$ \\
\hline DENV-1 & 450.0 & 316 & $>6$ & 6 \\
\hline DENV-2 & 174.2 & 317 & $>6$ & 5 \\
\hline DENV-4 & 632.7 & 416 & $>6$ & 4 \\
\hline
\end{tabular}

a Effective concentration required to reduce virus-induced cytopathogenicity by $50 \%$; ${ }^{b}$ Effective concentration required for inhibition of virus yield; ${ }^{\mathrm{c}}$ Seletivity index $\left(\mathrm{CC}_{50}\right.$ divide by $\left.\mathrm{EC}_{50}\right)$; ${ }^{\mathrm{d}} \mathrm{Calculated}$ from confluent cells, $\mathrm{CC}_{50}>3000 \mu \mathrm{g} / \mathrm{mL}$; ${ }^{\mathrm{e}}$ Calculated from exponentially growing cells, $\mathrm{CC}_{50}=2500 \mu \mathrm{g} / \mathrm{mL}$. 
Crance and co-workers evaluated glycyrrhizin (57), the major component responsible for the sweet-tasting constituent of Glycyrrhiza glabra (liquorice) root, against eleven flaviviruses including DENV-1, DENV-2, and DENV-3 [67]. The antiviral evaluation was performed in vitro with Vero cells by plaque reduction assay. Several bioactivities were determined for this compound and they are summarized in Table 5. This antiviral compound has already been used in patients in the treatment of other diseases. It should be further considered for use, either alone or in combination with another antiviral compounds tested in this work (interferon, ribavirin, 6-azauridine) for the treatment of flavivirus infections.

Narasin (58) is a polyether antibiotic and antibacterial produced by fermentation of Streptomyces aureofaciens. A dose-dependent study revealed that $\mathbf{5 8}$ has a 50\% inhibitory concentration of less than $1 \mu \mathrm{mol} / \mathrm{L}$ against all four DENV serotypes [68]. Minimal cytotoxicity was determined for this compound $(50 \%$ cytotoxic concentration $>1,000 \mu \mathrm{mol} / \mathrm{L})$. In vitro assays with Huh-7 cells by plaque assay with different concentrations, qRT-PCR, western blotting and ultrastructural imaging were performed in this investigation. Narasin (58) treatment of DENV-2 infected Huh-7 cells suggested that the compound is involved in inhibiting the post-entry stages of viral replication during DENV infection. The antiviral mechanism of narasin (58) is likely to be associated with the disruption of viral protein synthesis. No differences of RNA levels were found between narasin (58) treated and DENV-2 infected cells. The study indicated a characteristic disruption of viral protein synthesis by substance (58) without affecting viral RNA replication. However, a more detailed investigation is required to understand the exact molecular mechanism of narasin (58) in the inhibition of DENV protein synthesis and replication [68].

The acetylenic compounds 59-62 were isolated from an ethyl acetate extract of Anacolosa pervilleana, a Madagascan plant. By using purified DENV RdRp polymerase in enzyme assay, it was found that acetylenic compounds 59-62 give rise to $\mathrm{IC}_{50}$ values around $3 \mu \mathrm{mol} / \mathrm{L}$ in the DENV RdRp assay. The results show that compounds possess some selectivity toward DENV RdRp. All compounds except 59 showed an overall antimetabolic effect in Vero cells (CC50s between 20 and $30 \mu \mathrm{mol} / \mathrm{L}$ ). The presence of an additional acidic group in compound 59, probably prevents its penetration through the cell membrane, which may explain the absence of cytotoxicity [69].

\section{Conclusions}

During the last decades, the exploitation of the natural product pool has afforded a variety of compounds possessing activity against dengue virus serotypes. In several cases, very interesting activities are associated with the described compounds. It can be stated, though, that only a small fraction of the vast reservoir of compounds available from nature has been explored with the aim to find antivirus effective against dengue. From nature, it is possible that effective dengue antiviral compounds with low toxicity to human beings will certainly be found. Moreover, the structures of the natural compounds can serve as prototypes that can be optimized by synthetic campaigns in order to find even more active substances against dengue virus.

Most of the studies herein described were conducted in vitro using different plaque assays, including the focus forming assay, plaque reduction assay, plaque titration assay, virus yield reduction assay and MMT colorimetric assay. Some of these studies $[38,39,47,49,50,54,56,57,64,65,68]$ sought 
to use more than one methodology to perform and/or verify the antiviral activity, giving greater strength to the results. Only three authors conducted in vivo studies $[45,56]$, using animals, which further demonstrates the urgent need to make progress in these experiments to find a useful and effective antiviral against dengue. All of them were associated with in vitro assays. Seven enzyme assays, four against DENV NS5 polymerase [51,58,63,69] and three against DENV NS2B/NS3 protease $[48,55,64]$ were conducted. The tests used are well established and are ideal for this type of research. It is also necessary to carry out more extensive studies both in vitro and in vivo followed by toxicity and clinical tests to further evaluate the potential of compounds obtained from nature as dengue antivirals. Finally, subsequent in vivo testing will indicate which of these substances are going to be the most promising in antiviral therapies against dengue, since efficiency in vitro does not necessarily have a parallel in vivo.

\section{Acknowledgments}

We are grateful to FAPEMIG (for a research fellowship to AM da S) and CNPq. The funders had no role in the study design, data collection, analysis, decision to publish, or preparation of this manuscript.

\section{Author Contributions}

Authors contributed equally for the preparation of this review.

\section{Conflicts of Interest}

The authors declare no conflict of interest.

\section{References}

1. Kroeger, A.; Nathan, M.B. Dengue: Setting the global research agenda. Lancet 2006, 368, 2193-2195.

2. Gubler, D.J. Epidemic dengue/dengue hemorrhagic fever as a public health, social and economic problem in the 21st century. Trends Microbiol. 2002, 10, 100-103.

3. Normile, D. Surprising new dengue virus throws a spanner in disease control efforts. Science 2013, 342, 415.

4. Gubler, D.J.; Clark, G.G. Dengue/dengue hemorrhagic fever: The emergence of a global health problem. Emerg. Infect. Dis. 1995, 1, 55-57.

5. Chambers, T.J.; Hahn, C.S.; Galler, R.; Rice, C.M. Flavivirus genome organization, expression, and replication. Annu. Rev. Microbiol. 1990, 44, 649-688.

6. Gubler, D.J. Dengue and dengue hemorrhagic fever. Clin. Microbiol. Rev. 1998, 11, 480-496.

7. Wright, P.F.; Durbin, A.P.; Whitehead, S.S.; Ikizler, M.R.; Henderson, S.; Blaney, J.E.; Thumar, B.; Ankrah, S.; Rock, M.T.; McKinney, B.A.; et al. Phase 1 trial of the dengue virus type 4 vaccine candidate rDEN4\{Delta\}30-4995 in healthy adult volunteers. Am. J. Trop. Med. Hyg. 2009, 81, 834-841. 
8. Messina, J.P.; Brady, O.J.; Scott, T.W.; Zou, C.; Pigott, D.M.; Duda, K.A.; Bhatt, S.; Katzelnick, L.; Howes, R.E.; Battle, K.E.; et al. Global Spread of virus types: Mapping the 70 year history. Trends Microbiol. 2014, 22, 138-146.

9. World Health Organization (WHO). Dengue: Guidelines for Diagnosis, Treatment, Prevention and Control; WHO: Geneva, Switzerland, 2009; pp. 25-58.

10. Simmons, C.P.; Farrar, J.J.; Nguyen, V.V.; Wills, B. Dengue. N. Eng. J. Med. 2012, 366, 1423-1432.

11. Maves, R.C.; Ore, R.M.; Porter, K.R.; Kochel, T.J. Immunogenicity andprotective efficacy of a psoralen-inactivated dengue-1 virus vaccine candidate in Aotusnancymaae monkeys. Vaccine 2011, 29, 2691-2696.

12. Tassniyom, S.; Vasanawathana, S.; Chirawatkul, A.; Rojanasuphot, S. Failure of high-dose methylprednisolone in established dengue shock syndrome: A placebo-controlled, double-blind study. Pediatrics 1993, 92, 111-115.

13. Beatty, M.E.; Beutels, P.; Meltzer, M.I.; Shepard, D.S.; Hombach, J.; Hutubessy, R.; Dessis, D.; Coudeville, L.; Dervaux, B.; Wichmann, O.; et al. Health economics of dengue: A systematic literature review and expert panel's assessment. Am. J. Trop. Med. Hyg. 2011, 84, 473-488.

14. Lim, S.P.; Wang, Q.Y.; Noble, C.G.; Chen, Y.L.; Dong, H.; Zou, B.; Yokokawa, F.; Nilar, S.; Smith, P.; Beer, D.; et al. Ten years of dengue drug discovery: Progress and prospects. Antivir. Res. 2013, 100, 500-519.

15. Tomlinson, S.M.; Malmstrom, R.D.; Watowich, S.J. New approaches to structure-based discovery of dengue protease inhibitors. Infect. Disord. Drug Targets 2009, 9, 327-343.

16. Phillipson, D.J. Phytochemistry and medicinal plants. Phytochemistry 2001, 56, 237-243.

17. Butler, M.S. The role of natural product chemistry in drug discovery. J. Nat. Prod. 2004, 67, 2141-2153.

18. Koehn, F.E.; Carter, G.T. The evolving role of natural products in drug discovery. Nat. Rev. Drug Discov. 2005, 4, 206-220.

19. Newman, D.J.; Cragg, G.M. Natural products as sources of new drugs over the last 25 years. J. Nat. Prod. 2007, 70, 461-477.

20. Baker, D.D.; Chu, M.; Oza, U.; Rajgarhia, V. The value of natural products to future pharmaceutical discovery. Nat. Prod. Rep. 2007, 24, 1225-1244.

21. Newman, D.J.; Cragg, G.M. Natural Products as sources of new drugs over the 30 years from 1981 to 2010. J. Nat. Prod. 2012, 75, 311-355.

22. Cordell, G.A.; Colvard, M.D. Natural products and traditional medicine: Turning on a paradigm. J. Nat. Prod. 2012, 75, 514-525.

23. Dos Santos, N.P.; Pinto, A.C. The forest is his pharmacy-the research of Brazilian plants to combat tropical diseases in the nineteenth century. Rev. Virtual Quim. 2012, 4, 162-172.

24. Kadir, S.L.A.; Yakoob, H.; Zulkifli, R.M. Potential anti-dengue medicinal plants: A review. J. Nat. Med. 2013, 67, 677-689.

25. World Health Organization. Traditional medicine. Available online: http://www.who.int/ mediacentre/factsheets/2003/fs134/en/ (accessed on 2 February 2014).

26. Betancur-Galvis, L.A.; Saez, J.; Granados, H.; Slazar, A.; Ossa, J.E. Antitumor and antiviral activity of Colombian medicinal plant extracts. Mem. Inst. Oswaldo. Cruz 1999, 94, 531-535. 
27. Kudi, A.C.; Myint, S.H. Antiviral activity of some Nigerian medicinal plants extracts. J. Ethnopharmacol. 1999, 68, 289-294.

28. Li, Bo; Lu, F.; Wei, X.; Zhao, R. Fucoidan: Structure and bioactivity. Molecules 2008, 13, 1671-1695.

29. Hidari, K.I.P.J.; Abe, T.; Suzuki, T. Carbohydrate-related inhibitors of dengue virus entry. Viruses 2013, 5, 605-618.

30. Fitton, J.H. Therapies from fucoidan; multifunctional marine polymers. Mar. Drugs 2011, 9, 1731-1760.

31. Hidari, K.I.P.J.; Takahashi, N.; Arihara, M.; Nagaoka, M.; Morita, K.; Suzuki, T. Structure and anti-dengue virus activity of sulfate polysaccharide from a marine alga. Biochem. Biophys. Res. Commun. 2008, 376, 91-95.

32. Marks, R.M.; Lu, H.; Sundaresan, R.; Toida, T.; Suzuki, A.; Imanari, T.; Hernáiz, M.J.; Linhardt, R.J. Probing the interaction of dengue virus envelope protein with heparin: Assessment of glycosaminoglycan-derived inhibitors. J. Med. Chem. 2001, 44, 2178-2187.

33. Estevez, J.M.; Ciancia, M.; Cerezo, A.S. DL-Galactan hybrids and agarans from gametophytes of the red seaweed Gymnogongrus. torulosus. Carb. Res. 2001, 331, $27-41$.

34. Talarico, L.B.; Zibetti, R.G.M.; Faria, P.C.S.; Scolaro, L.A.; Duarte, M.E.R.; Noseda, M.D.; Pujol, C.A.; Damonte, E.B. Anti-herpes simplex virus activity of sulfated galactans from the red seaweeds Gymnogongrus. griffithsiae and Cryptonemia. crenulata. Int. J. Biol. Biol. Macromol. 2004, 34, 63-71.

35. Paint, T.J. The Polysaccharides; Aspinall, G.O., Ed.; Academica Press: New York, NY, USA, 1983; Volume 2, pp. 195-285.

36. Kraan, S. Algal Polysaccharides, Novel Applications and Outlook; In Tech: Rijeka, Croatia, 2012; pp. 489-532.

37. Jiao, G.; Yu, G.; Zhang, J.; Ewart, H.S. Chemical structures and bioactivities of sulfated polysaccharides from marine algae. Mar. Drugs 2011, 9, 196-223.

38. Talarico, L.B.; Damonte, E.B. Interference in dengue virus adsorption and uncoating by carrageenans. Virology 2007, 363, 473-485.

39. Talarico, L.B.; Pujol, C.A.; Zibetti, R.G.M.; Faría, P.C.S.; Noseda, M.D.; Duarte, M.E.R.; Damonte, E.B. The antiviral activity of sulfated polysaccharides against dengue virus is dependent on virus serotype and host cell. Antivir. Res. 2005, 66, 103-110.

40. Tischer, P.C.S.F.; Talarico, L.B.; Noseda, M.D.; Guimarães, S.M.P.B.; Damonte, E.B.; Duarte, M.E.R. Chemical structure and antiviral activity of carrageenans from Meristiella gelidium against herpes simplex and dengue virus. Carbohyd. Polym. 2006, 63, 459-465.

41. Pujol, C.A.; Estevez, J.M.; Carlucci, M.J.; Ciancia, M.; Cerezo, A.S.; Damonte, E.B. Novel DL-galactan hybrids from the red seaweed Gymnogongrus torulosus are potent inhibitors of herpes simplex virus and dengue virus. Antivir. Chem. Chemoth. 2002, 13, 83-89.

42. Liang, W.; Mao, X.; Peng, X.; Tang, S. Effects of sulfate group in red seaweed polysaccharides on anticoagulant and cytotoxicity. Carbohydr. Polym. 2014, 101, 776-785.

43. Srivastava, M.; Kapoor, V.P. Seed galactomannas: An overview. Chem. Biodivers. 2005, 2, 295-317. 
44. Secouard, S.; Grisel, M.; Malhiac, C. Flavour release study as a way to explain xanthangalactomannan interactions. Food Hydrocolloid. 2007, 21, 1237-1244.

45. Ono, L.; Wollinger, W.; Rocco, I.M.; Coimbra, T.L.M.; Gorin, P.A.J.; Sierakowski, M.-R. In vitro and in vivo antiviral properties of sulfated galactomannans against yellow fever virus (BeH111 strain) and dengue 1 virus (Hawaii strain). Antiviral Res. 2003, 60, 201-208.

46. Sánchez, I.; Garibay, F.G.; Taboada, J.; Ruiz, B.H. Antiviral effect of flavonoids on the dengue virus. Phytother. Res. 2000, 14, 89-92.

47. Leardkamolkarn, V.; Sirigulpanit, W.; Phurimsak, C.; Kumkate, S.; Himakoun, L.; Sripanidkulchai, B. The inhibitory actions of Houttuynia cordata aqueous extract on dengue virus and dengue-infected cells. J. Food Biochem. 2012, 36, 86-92.

48. Kiat, T.S.; Pippen, R.; Yusof, R.; Ibrahim, H.; Khalid, N.; Rahman, N.A. Inhibitory activity of cyclohexenyl chalcone derivatives and flavonoids of fingerrot, Boesenbergia rotunda (L.), towards dengue-2 virus NS3 protease. Bioorg. Med. Chem. Lett. 2006, 16, 3337-3340.

49. Zandi, K.; Teoh, B.T.; Sam, S.S.; Wong, P.F.; Mustafa, M.R.; Abubakar, S. Antiviral activity of four types of bioflavonoid against dengue virus type-2. Virol. J. 2011, 8, 1-11.

50. Zandi, K.; Teoh, B.T.; Sam, S.S.; Wong, P.F.; Mustafa, M.R.; AbuBakar, S. In vitro antiviral activity of fisetin, rutin and naringenin against Dengue virus type-2. J. Med. Plants Res. 2011, 5, 5534-5539.

51. Allard, P.M.; Dau, E.T.H.; Eydoux, C.; Guillemot, J.C.; Dumontet, V.; Poullain, C.; Canard, B.; Guérrite, F.; Litaudon, M. Alkylated flavanones from the bark of Cryptocarya. chartacea as dengue virus NS5 polymerase inhibitors. J. Nat. Prod. 2011, 11, 2446-2453.

52. Zandi, K.; Teoh, B.T.; Sam, S.S.; Wong, P.F.; Mustafa, M.R.; AbuBakar, S. Novel antiviral activity of baicalein agains dengue virus. BMC Complement. Altern. Med. 2012, 12, 1-9.

53. Simões, L.R.; Maciel, G.M.; Brandão, G.C.; Kroon, E.G.; Castilho, R.O.; Oliveira, A.B. Antiviral activity of Distictella. elongate (Vahl) Urb. (Bignoniaceae), a potentially useful source of antidengue drugs from the state of Minas Gerais, Brazil. Lett. Appl. Microbiol. 2011, 53, 602-607.

54. Low, J.S.Y.; Chen, K.C.; Wu, K.X.; Ng, M.M.L.; Chu, J.J.H. Antiviral activity of emetine dihydrochloride against dengue virus infection. J. Antivir. Antiretrovir. 2009, 1, 062-071.

55. Jia, F.; Zou, G.; Fan, J.; Yuan, Z. Identification of palmatine as an inhibitor of West Nile virus. Arch. Virol. 2010, 155, 1325-1329.

56. Whitby, K.; Pierson, T.C.; Geiss, B.; Lane, K.; Engle, M.; Zhou, Y.; Doms, R.W.; Diamond, M.S. Castanospermine, a potent inhibitor of dengue virus infection in vitro and in vivo. J. Virol. 2005, 79, 8698-8706.

57. Zhang, X.G.; Mason, P.W.; Dubovi, E.J.; Xu, X.; Bourne, N.; Renshaw, R.W.; Block, T.M.; Birk, A.V. Antiviral activity of geneticin against dengue virus. Antivir. Res. 2009, 83, 21-27.

58. Allard, P.M.; Leyssen, P.; Martin, M.T.; Bourjot, M.; Dumontet, V.; Eydoux, C.; Guillemot, J.C.; Canard, B.; Poullain, C.; Guérrite, F. Antiviral chlorinated daphnane diterpenoid orthoesters from the bark and wood of Trigonostemon cherrieri. Phytochemistry 2012, 84, 160-168.

59. Brandão, G.C.; Kroon, E.G.; Souza, D.E.R.; Filho, J.D.S.; Oliveira, A.B. Chemistry and antiviral activity of Arrabidaea pulchra (Bignoniaceae). Molecules 2013, 18, 9919-9932.

60. Hamann, M.; Donia, M. Marine natural products and their potential applications as anti-infective agents. Lancet 2003, 3, 338-348. 
61. Laille, M.; Gerald, F.; Debitus, C. In vitro antiviral activity on dengue virus of marine natural products. Cell. Mol. Life Sci. 1998, 54, 167-170.

62. Laurent, D.; Baumann, F.; Benoit, A.G.; Mortelecqe, A.; Nitatpattana, N.; Desvignes, I.; Debitus, C.; Laille, M.; Gonzales, J.P.; Chungue, E. Structure-activity relationships of dengue antiviral polycyclic quinones. Southeast. Asian J. Trop. Med. Public Health 2005, 36, 901-905.

63. Bourjot, M.; Leyssen, P.; Eydoux, C.; Guillemot, J.C.; Canard, B.; Rasoanaivo, P.; Guérrite, F.; Litaudon, M. Flacourtosides A.F.phenolic glycosides isolated from Flacourtia. ramontchi. J. Nat. Prod. 2012, 75, 752-758.

64. Rahman, N.A.; Hadinur, B.; Muliawan, S.; Rashid, N.N.; Muhamad, M.; Yusof, R. Studies on Quercus. lusitanic extracts on DENV-2 replication. Deng. Bull. 2006, 30, 260-269.

65. Rees, C.R.; Costin, J.M.; Fink, R.C.; McMichael, M.; Fontaine, K.A.; Isern, S.; Michael, S.F. In vitro inhibition of dengue virus entry by $p$-sulfoxy-cinnamic acid and structurally related combinatorial chemistries. Antivir. Res. 2008, 80, 135-142.

66. Zasloff, M.; Adams, A.P.; Beckerman, B.; Campbell, A.; Han, Z.; Luijten, E.; Meza, I.; Julander, J.; Mishra, A.; Qu, W.; et al. Squalamine as a broad-spectrum systemic antiviral agent with therapeutic potential. Proc. Natl. Acad. Sci. USA 2011, 108, 15978-15983.

67. Crance, J.M.; Scaramozzino, N.; Jouan, A.; Garin, D. Interferon, ribavirin, 6-azauridine and glycyrrhizin: Antiviral compounds active against pathogenic flaviviruses. Antivir. Res. 2003, 58, 73-79.

68. Low, J.S.Y.; Wu, K.X.; Chen, K.C.; Ng, M.M.L.; Chu, J.J.H. Narasin, a novel antiviral compound that blocks dengue virus protein expression. Antivir. Ther. 2011, 16, 1203-1218.

69. Bourjot, M.; Leyssen, P.; Eydoux, C.; Guillemot, J.C.; Canard, B.; Rasoanaivo, P.; Guérrite, F.; Litaudon, M. Chemical constituents of Anacolosa. pervilleana and their antiviral activities. Fitoterapia 2012, 83, 1076-1080.

Sample Availability: Samples of the compounds described in this review are not available from the authors.

(C) 2014 by the authors; licensee MDPI, Basel, Switzerland. This article is an open access article distributed under the terms and conditions of the Creative Commons Attribution license (http://creativecommons.org/licenses/by/3.0/). 